\title{
Zinc Modulates Nanosilver-Induced Toxicity in Primary Neuronal Cultures
}

\author{
Elżbieta Ziemińska ${ }^{1} \cdot$ Lidia Strużyńska $^{2}$
}

Received: 11 August 2015/Revised: 23 November 2015/Accepted: 28 November 2015/Published online: 21 December 2015

(C) The Author(s) 2015. This article is published with open access at Springerlink.com

\begin{abstract}
Silver nanoparticles (NAg) have recently become one of the most commonly used nanomaterials. Since the ability of nanosilver to enter the brain has been confirmed, there has been a need to investigate mechanisms of its neurotoxicity. We previously showed that primary neuronal cultures treated with nanosilver undergo destabilization of calcium homeostasis via a mechanism involving glutamatergic NMDA receptors. Considering the fact that zinc interacts with these receptors, the aim of the present study was to examine the role of zinc in mechanisms of neuronal cell death in primary cultures. In cells treated with nanosilver, we noted an imbalance between extracellular and intracellular zinc levels. Thus, the influence of zinc deficiency and supplementation on nanosilver-evoked cytotoxicity was investigated by treatment with TPEN (a chelator of zinc ions), or $\mathrm{ZnCl}_{2}$, respectively. Elimination of zinc leads to complete death of nanosilver-treated CGCs. In contrast, supplementation with $\mathrm{ZnCl}_{2}$ increases viability of CGCs in a dose-dependent manner. Addition of zinc provided protection against the extra/intracellular calcium imbalance in a manner similar to MK-801, an antagonist of NMDA receptors. Zinc chelation by TPEN decreases the mitochondrial potential and dramatically increases the rate of production of reactive oxygen species. Our results indicate
\end{abstract}

Lidia Strużyńska

lidkas@imdik.pan.pl

1 Laboratory of Pharmaconeurochemistry, Department of Neurochemistry, Mossakowski Medical Research Centre, Polish Academy of Sciences, 5 Pawińskiego str, 02-106 Warsaw, Poland

2 Laboratory of Pathoneurochemistry, Department of Neurochemistry, Mossakowski Medical Research Centre, Polish Academy of Sciences, 5 Pawińskiego str, 02-106 Warsaw, Poland that zinc supplementation positively influences nanosilverevoked changes in CGCs. This is presumed to be due to an inhibitory effect on NMDA-sensitive calcium channels.

Keywords Nanotoxicity - Zinc homeostasis - TPEN · Free radicals $\cdot$ NMDA receptor $\cdot$ Cell death

$\begin{array}{ll}\begin{array}{l}\text { Abbreviations } \\ \text { AMPA/KA receptors }\end{array} & \begin{array}{l}\text { Glutamatergic AMPA and kainate } \\ \text { receptors }\end{array} \\ \text { BME } & \begin{array}{l}\text { Basal Eagle's medium } \\ \text { Cerebellar granule cells } \\ \text { CGC }\end{array} \\ \text { CNS } & \text { Central nervous system } \\ \text { DCF } & 2^{\prime} \text {-Dichlorofluoresce in diacetate } \\ \text { EtHD } & \text { Ethidium homodimer } \\ \text { FCS } & \text { Fetal calf serum } \\ \text { MK-801 } & \text { Noncompetitive antagonist of } \\ & \text { NMDA receptor } \\ \text { NAg } & \text { Silver nanoparticles } \\ \text { NMDAR } & \text { Glutamatergic } N \text {-methyl-D- } \\ \text { PVP } & \text { aspartate receptor } \\ \text { R123 } & \text { Polyvinylpyrrolidone } \\ \text { ROS } & \text { Rhodamine123 } \\ \text { TEM } & \text { Reactive oxygen species } \\ \text { TPEN } & \text { Transmission electron microscopy } \\ \text { Zn-T1, Zn-T2, Zn-T3 } & N, N, N, N \text {-tetrakis }(2- \\ & \text { pyridylmethyl)ethylenediamine } \\ & \text { Transmembrane zinc transporters }\end{array}$

\section{Introduction}

In recent years, silver nanoparticles (NAg) have become an extremely popular nanotechnology product widely used in many applications. Their strong antibacterial potential is 
useful in medical products (Samuel and Gugenbichler 2004; Zheng et al., 2010) and they are also found in a growth market of consumer articles (for review see: Schluesener and Schluesener 2013). Thus, as the risk of increased human exposure appears, further information on cellular metabolic pathways affected by nanosilver is needed.

Cytotoxicity of nanosilver has been confirmed in both in vitro and in vivo studies (Haase et al. 2012; Strużyński et al. 2014; Yin et al. 2013) indicating that the induction of oxidative stress underlies nanosilver-induced cell death. It has been reported that nanosilver has an influence on mitochondrial function, generation of free radicals (AshaRani et al. 2009; Hussain et al. 2005; Singh and Ramarao 2012) and induction of apoptosis due to lowering of the cellular antioxidant glutathione (Piao et al. 2011). The high reactivity of NAg, resulting in enhanced ability to cross cell membranes, is of great concern in neuroscience due to the progressive development of theragnosis, a new concept in next-generation medicine that combines simultaneous diagnosis and therapy with the use of nanoparticles, including NAg (Leite et al. 2015). Since NAg have been shown to enter the brain by permeating the bloodbrain barrier (BBB) (Hoet et al. 2004; Sharma et al. 2009) and significantly accumulate in this organ, it is important to clarified their neurotoxic effects.

We have previously investigated the mechanisms of cell death in cultured cerebellar granule cells (CGC) exposed to silver nanoparticles (Ziemińska et al. 2014). The results of this study indicated that overactivation of glutamatergic $\mathrm{N}$ methyl-D-aspartate receptors (NMDARs) is involved in neuronal cell death via excessive entry of calcium ions followed by an intracellular calcium imbalance. However, it has been shown that in addition to calcium, zinc ( $\mathrm{Zn}$ ) may have a negative effect on cell function in a process which leads to cell death (Lozier et al. 2012). In glutamatergic neurons, zinc is largely co-localized with the excitatory neurotransmitter glutamate (Frederickson 1989) and is synaptically released upon cell activation (Assaf and Chung 1984). If so, under the excitotoxic conditions produced by overactivation of glutamatergic receptors, it is probable that excessive levels of extracellular zinc exist. In view of the data indicating that $\mathrm{Zn}$ may modify voltageand ligand-gated channels (Harrison and Gibson 1994), and especially NMDA receptor channels (Peters et al. 1987), we suspect that zinc is playing an important role in the pathological mechanisms operating during nanosilver-mediated toxicity toward CGCs in our experimental design.

Zinc plays an important role in a wide variety of cellular processes as a cofactor of more than 300 enzymes involved in a majority of metabolic processes (Beyersmann and Haase 2001). In neuronal cells, deregulation of zinc homeostasis may occur as a consequence of an imbalance between synaptic and intracellular pools of this metal. It has been shown that this may contribute to neuronal cell death in numerous pathologies of the CNS, including ischemia and seizures (Koh et al. 1996; Tonder et al. 1990).

It is known that zinc has a dual effect in cell, neurotoxic, or neuroprotective, although mechanisms of its action are not precisely known (Sobieszczańska et al. 2012), particularly under pathological conditions. Intracellular zinc is bound to the cell membranes and cytoplasmic proteins (structural zinc) or is present in the cytoplasm as so called "free zinc" (Vallee and Falchuk 1993). In the CNS, zinc is also present at relatively high levels pooled within synaptic vesicles together with glutamate in glutamatergic neurons.

There are several mechanisms maintaining cellular zinc homeostasis. These mechanisms involve metallothioneins (Aschner et al. 1997) and specific transporters (Palmiter and Findley 1995). Transmembrane transporter Zn-T1 exports zinc ions out of the cell; Zn-T2 and Zn-T3 are, respectively, responsible for transporting zinc ions from the cytoplasm to endosomes and synaptic vesicles. The proper zinc gradient (which is lower inside than outside the cell) is provided by energy-dependent process. Thus, under conditions leading to decreased ATP production, the intracellular zinc concentration increases. This also occurs in response to oxidative stress resulting from the release of zinc from metallothioneins (Aizmenman et al. 2000). Other processes leading to enhanced release of zinc from glutamatergic nerve endings may result in zinc entering the cell through voltage-gated calcium channels (Kim et al. 2000) or AMPA/KA glutamate receptors (Sensi et al. 1997). An excess of intracellular zinc disturbs oxygen metabolism by inhibiting mitochondrial electron transport, disrupts calcium homeostasis, and overactivates calcium-mediated enzymes leading finally to cell death (Trombley et al. 2000; Lobner et al. 2000).

Thus, in the present paper, we investigate further mechanisms of cell death under nanosilver toxicity conditions, with particular attention to the role of zinc ions. Cerebellar granule cells (CGCs) cultured in the presence of nanosilver are studied under conditions of zinc deficiency and increased levels of zinc.

\section{Materials and Methods}

\section{Materials}

Fluo-3AM, FluoZin-1, FluoZin-3AM, 6-Carboxy-2', $7^{\prime}$ dichlorofluorescein diacetate (DCF), and rhodamine 123 (R123) were obtained from Molecular Probes (Eugene, OR, USA). ${ }^{45} \mathrm{CaCl}_{2}$ was produced by Polatom Sp. z o.o., Otwock-Swierk, Poland. Other chemicals, including nanosilver and cell culture materials were purchased from 
Sigma-Aldrich Chemical Co. (St. Louis, MO, USA). All reagents were of analytical grade.

\section{Preparation of Silver Nanoparticles (NAg)}

Commercially available nanosilver was used in the present study. Nanosilver is defined by the manufacturer (SigmaAldrich) as a mixture of polyvinylpyrrolidone-coated nanoparticles ( $0.2 \%$ PVP-coated nanosilver) less than $100 \mathrm{~nm}$ in diameter. We previously characterized and investigated nanosilver produced by this manufacturer in toxicological studies (Strużyńska et al. 2014; Zieminska et al. 2014). However, for the purpose of the present work, characterization of the degree of dispersion and particle size distribution was performed using transmission electron microscopic analysis (JEM-1200EX, Jeol) both in stock solution with fetal calf serum (FCS) and in exposure media (BME, Locke buffer).

A stock solution of nanosilver in fetal calf serum was freshly prepared just prior to its addition to the CGC culture $\left(2 \times 10^{6} /\right.$ well $)$ in order to avoid the release of $\mathrm{Ag}^{+}$ ions from the particle surface (Kittler et al. 2010). Stock solution was sonicated in proper conditions $(6 \times 20 \mathrm{~s}$, $35 \mathrm{~W}$, BANDELIN sonoplus HD 70) to prevent sedimentation and agglomeration of nanoparticles as well as hitting of the solution and denaturation of serum proteins. Additionally, stock solution was filtered using a $0.22-\mu \mathrm{M}$ microfilter.

The same volume of supernatant (obtained after centrifugation of above-described stock solution of NAg at $15,000 \times g, 30 \mathrm{~min}$ ), containing $\mathrm{Ag}^{+}$liberated from the nanoparticle surface, was used as a control to define the effects characteristic for ionic or "nano" form of silver. Absence of nanoparticles in supernatant was confirmed using TEM.

We also check whether NAg, under absence of biological material, interact with fluorescent dyes used in further experiments and we noticed any interference.

\section{Cell Culture and Experimental Design of Nanosilver Cytotoxicity}

Primary cultures of cerebellar granule cells (CGCs) were prepared from 7-day-old Wistar rats of both sexes as described previously (Ziemińska et al. 2010, 2014). Procedures using rat pups were performed in accordance with international standards of animal care guidelines and were approved by the Local Care of Experimental Animals Committee. Briefly, after decapitation, cerebella were rapidly removed, cut into $400 \mu \mathrm{m}$ cubes, and subjected to trypsinization. After centrifugation, the cells were suspended in basal Eagle's medium (BME) and seeded on plates (NUNC) coated with poly-L-lysine, at a densities of
$4 \times 10^{6}, 2 \times 10^{6}$ or $1 \times 10^{6}$ cells per well or $15 \times 10^{6}$ per flash. In each case, the cell suspension was supplemented with $10 \%$ fetal calf serum, $25 \mathrm{mM} \mathrm{KCl}, 4 \mathrm{mM}$ glutamine, streptomycin $(50 \mu \mathrm{g} / \mathrm{mL})$, and penicillin $(50 \mathrm{U} /$ $\mathrm{mL}$ ). The CGCs were used in experiments after 7 days.

On the 7th day of culture, serum solutions of nanosilver $(\mathrm{NAg}) /$ supernatant $\left(\mathrm{Ag}^{+}\right)$were added directly to BME growth medium to obtain final concentrations in the range of $2.5-10$ or $75 \mu \mathrm{g} / \mathrm{mL}$. In most experiments, nanosilver in concentration of $75 \mu \mathrm{g} / \mathrm{mL}$ (NAg 75) and supernatant obtained from this solution (super 75) were applied. In serum, nanoparticles sediment very slowly and this characteristic provides reproducibility during addition to the cultures. However, since serum contains trace amounts of its own glutamate, calcium, and zinc ions, it is also necessary to compare the results obtained for NAg with control culture supplemented with the volume of serum equal to the volume of NAg or supernatant added to the experimental system (control + serum 75). The final concentration of FCS in this experimental design was $10.75 \%$. Apart from this, untreated cells were also used as a negative control.

Additionally, the culture medium contained $20 \mu \mathrm{M}$ of the selective zinc ions chelator TPEN $(20 \mu \mathrm{M} \mathrm{N}, N, N, N$ tetrakis(2-pirydylmethyl) ethylenediamine), $\quad 10-50 \mu \mathrm{M}$ $\mathrm{ZnCl}_{2}$ or $0.5 \mu \mathrm{M}$ of MK-801 (an antagonist of glutamatergic NMDA receptors), or $10-50 \mu \mathrm{M}$ CNQX (an antagonist of AMPA/KA glutamatergic receptors). The cells were cultured for $24 \mathrm{~h}$ and then the viability of neurons was assessed by staining with $0.5 \mu \mathrm{g} / \mathrm{ml}$ propidium iodide (PI) or with the fluorescent dyes calcein and EtHD. PI is toxic for the neurons and stains only dead cells, so prior to staining with PI, the cells were fixed with $80 \%$ methanol. Cells that were alive in the time of fixation differed morphologically from dead ones. Fluorescence microscopy was employed to count living and dead neurons (Zeiss-Axiovert, Germany) as described previously (Ziemińska et al. 2010, 2014). Results were expressed as percentage of live cells in proportion to all cells.

To visualize changes in nuclear chromatin, LSM 510 confocal microscope (Carl Zeiss AG, Germany) was used. Images of fixed and PI-stained cells were recorded using $546 \mathrm{~nm} \mathrm{HeNe}$ laser for excitation of fluorescence. The emission was measure at $\lambda 617 \mathrm{~nm}$. Studies using confocal microscopy were performed in Laboratory of Advanced Techniques, Mossakowski Medical Research Centre, Polish Academy of Sciences.

\section{Measurement of Intracellular Zinc Levels with Fluorescent Dye FluoZin-3AM}

Changes in the intracellular $\mathrm{Zn}^{2+}$ concentration were measured fluorometrically. The cells $\left(1 \times 10^{6} /\right.$ well $)$ were 
incubated at $37{ }^{\circ} \mathrm{C}$ for $60 \mathrm{~min}$ in growth medium with $3 \mu \mathrm{M}$ FluoZin-3AM. Then, the cells were twice washed with Locke 5 medium and examined using confocal microscope (LSM 510, Carl Zeiss AG, Germany) after addition of $\mathrm{NAg} / \mathrm{Ag}^{+}$. The fluorescence of FluoZin-3 induced by argon laser at $488 \mathrm{~nm}$ was measured at $530 \mathrm{~nm}$ every $30 \mathrm{~s}$ during $15 \mathrm{~min}$. The results are presented as percentage changes in the intensity of fluorescence in relation to its basal level $\left(F / F_{\mathrm{o}}\right)$. The data were obtained from three independent trials using separate CGC cultures and presented as means of 15 randomly selected objects.

\section{Measurement of Zinc Levels with Fluorescent Dyes FluoZin-1}

CGCs $\left(15 \times 10^{6} /\right.$ bottle $)$ were transferred to Locke 25 medium and incubated 30 min with $75 \mu \mathrm{g} / \mathrm{mL} \mathrm{NAg}$ or $\mathrm{Ag}^{+}$ in the presence of $0.75 \%$ FCS. Then, to avoid interference with extracellular zinc from serum, the cells were three times washed with fresh Locke medium containing $154 \mathrm{mM} \mathrm{NaCl}, 5 \mathrm{mM} \mathrm{KCl}, 4 \mathrm{mM} \mathrm{NaHCO}_{3}, 2.3 \mathrm{mM}$ $\mathrm{CaCl}_{2}, 5 \mathrm{mM}$ HEPES (pH 7.4), and $5 \mathrm{mM}$ glucose. Since the probe does not penetrate the membrane, the cells from each bottle were lysed in $0.5 \mathrm{M} \mathrm{NaOH}$ to provide visualization of zinc in the intracellular space. Then $100 \mu \mathrm{L}$ of solution was incubated with $1 \mu \mathrm{M}$ FluoZin-1 and fluorescence was measured using a microplate reader (FLUOstar Omega, Germany) at $485 \mathrm{~nm}$ excitation and $538 \mathrm{~nm}$ emission wavelengths. Addition of $\mathrm{NaOH}$ alone had no effect on the readout of fluorescence (control with Locke solution with $\mathrm{ZnCl}_{2}$ versus the same concentration of $\mathrm{ZnCl}_{2}$ in $\mathrm{NaOH}$ ).

\section{Uptake of Radioactive Calcium}

The cells $\left(4 \times 10^{6} /\right.$ well $)$ were pre-incubated at $37{ }^{\circ} \mathrm{C}$ for $10 \mathrm{~min}$ in Locke 5 medium. Radioactive calcium $(1 \mu \mathrm{Ci} /$ well) was added together with $75 \mu \mathrm{g} / \mathrm{mL} \mathrm{NAg} / \mathrm{Ag}^{+}$or other substances and after $10 \mathrm{~min}$ incubation at $37^{\circ} \mathrm{C}$, the cells were washed $3 \times$ with ice-cold glucose and calciumfree medium containing $2 \mathrm{mM}$ EGTA. After lysing the cells in $0.5 \mathrm{M} \mathrm{NaOH}$, radioactive calcium uptake was measured using a Wallac 1409 liquid scintillation counter (Wallac, Turku, Finland).

\section{Loading of Cells with fluo-3 AM and Fluorescence Measurements}

CGCs $\left(1 \times 10^{6} /\right.$ well $)$ were loaded with the fluorescent calcium-sensitive probe, $4 \mu \mathrm{M}$ fluo- $3 \mathrm{AM}$, at $37^{\circ} \mathrm{C}$ for $30 \mathrm{~min}$. The cells were washed with the Locke 5 buffer to terminate loading. Changes in fluorescence after addition of all tested compounds were recorded at 1-min intervals over a 30-min period, using a microplate reader (FLUOstar Omega, Germany) at 485-nm excitation and 538-nm emission wavelengths.

\section{Measurement of Mitochondrial Membrane Potential in CGC}

Rhodamine123 (R123) was added to the cultures $\left(1 \times 10^{6} \%\right.$ well) to a final concentration of $10 \mu \mathrm{M}$ for $30 \mathrm{~min}$ at $37^{\circ} \mathrm{C}$. Decrease in mitochondrial membrane potential was monitored by increased intracellular fluorescence. After preincubation with R123, cells were washed with Locke 5

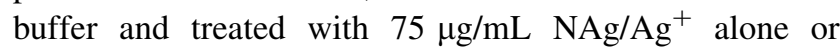
mixed with other tested compounds. Changes of fluorescence were recorded every $3 \mathrm{~min}$, over a 1 -h period, using a microplate reader (Fluoroscan, LabScan, Finland) at 485-nm excitation and 538-nm emission wavelengths.

\section{Measurement of Free Radicals Production in CGC}

The fluorescent dye $2^{\prime}, 7^{\prime}$-dichlorofluorescin diacetate (DCF) was added to the cultures to a final concentration of $100 \mu \mathrm{M}$ and used to evaluate free radical production. After a 30-min incubation period, cells $\left(1 \times 10^{6} /\right.$ well $)$ were washed with Locke 5 buffer and treated with $75 \mu \mathrm{g} / \mathrm{mL}$ nanosilver, supernatant alone, or in combination with other tested compounds. Changes in fluorescence were recorded at $1 \mathrm{~min}$ intervals, over a 30-min incubation period, using a microplate reader (FLUOstar Omega, Germany) at 485-nm excitation and 538-nm emission wavelengths.

\section{Statistical Analysis}

Results are expressed as mean $\pm \mathrm{SD}$ of the number of cultures indicated below each figure. Inter-group comparisons were made using the one-way analysis of variance (ANOVA) with Bonferroni correction for multiple comparisons. The significance level was set as $P<0.05$.

\section{Results}

\section{Silver Nanoparticles}

Commercially available $0.2 \%$ polyvinylpyrrolidone (PVP)-coated nanosilver particles $<100 \mathrm{~nm}$ were used in the experiments. TEM studies revealed that the nanoparticles generally have a spherical shape and do not form aggregates in the stock solution either in the presence of serum or culture media (BME and Locke buffer). The size distribution estimation indicated that the vast majority $(88 \%)$ of nanosilver particles were between 5 and $25 \mathrm{~nm}$ in diameter and more than half $(65 \%)$ did not exceed 
$10 \mathrm{~nm}$ in diameter (Table 1). No nanoparticles were detected in the supernatant obtained after centrifugation of the stock solution of silver nanoparticles.

\section{Changes in the Level of Zinc in CGCs Exposed to Nanosilver Particles}

We examined whether incubation of cells with $\mathrm{NAg} / \mathrm{Ag}^{+}$ influences the level of total intracellular zinc and its cytosolic "free" pool. To assess cytosolic zinc changes, we used cell-permeable fluorescent dye FluoZin-3AM, a $\mathrm{Zn}^{2+}$ selective indicator, which exhibits high $\mathrm{Zn}^{2+}$-binding affinity unperturbed by $\mathrm{Ca}^{2+}$ concentrations up to at least $1 \mu \mathrm{M}$. In addition, this dye exhibits a $>50$-fold increase in fluorescence in response to saturating levels of $\mathrm{Zn}^{2+}$.

As it is seen (Fig. 1a, b), addition of $75 \mu \mathrm{g} / \mathrm{ml} \mathrm{NAg}$ results in a rapid (during $60 \mathrm{~s}$ ) and a very high (sevenfold) increase in cytosolic zinc level compared to its basal level in control untreated cells (max. time of signal recording $15 \mathrm{~min}$ ). In parallel, fluorescence was recorded in medium around the cells (Fig. 1b). It was significantly less pronounced after application of supernatant and did not occur when only serum was added. Since FluoZin-3 bounds only free zinc, we claimed that cytosolic pool of free zinc increases rapidly after NAg treatment and is subsequently partially released from the cell to the culture medium.

We also used fluorescent dye FluoZin-1 to measure the fluorescence intensity in cell lysates $\left(15 \times 10^{6}\right)$ over a longer period of time (after $30 \mathrm{~min}$ ). FluoZin-1 is a cellimpermeable indicator designed to detect zinc concentrations in the $0-100 \mu \mathrm{M}$ range with minimal interference with calcium sensitivity. Decreased fluorescence in cell lysates reflecting decrease in the intracellular zinc (total zinc i.e., free cytosolic and sequestered in cellular organelles) was noted after exposure to both $\mathrm{NAg}$ and $\mathrm{Ag}^{+}$. However, destabilization of cellular zinc equilibrium was

Table 1 The size distribution of silver nanoparticles in serum stock solution significantly more evident after exposure to nanosilver particles and reached about $20 \%(* P<0.05$ versus control) (Fig. 1c).

\section{Viability of Nanosilver-Treated CGC in the Presence or Absence of Zinc}

We have previously checked that application of NAg or supernatant $\left(\mathrm{Ag}^{+}\right)$in the concentration range of $2.5-25 \mu \mathrm{g} /$ $\mathrm{mL}$ exhibited no visible effect on the viability of neurons after $24 \mathrm{~h}$ of exposure (Ziemińska et al. 2014). The statistically significant decrease in cells viability occurred after addition of $\mathrm{NAg}$ in the concentrations $\geq 50 \mu \mathrm{g} / \mathrm{mL}$. The number of living cells declined in a dose-dependent manner from 60 to $30 \%$ of control value.

Results after addition of respective amounts of supernatant $\left(\mathrm{Ag}^{+}\right)$were generally comparable, but slightly greater in numbers of cells survived (55-70 \%) relative to respective doses of NAg. Thus, in the current experiments, we used the concentration of silver nanoparticles in the presence of which viability of neurons decreased to about $50 \%$ of control $(75 \mu \mathrm{g} / \mathrm{mL})$. Such marked dose-response effect allowed us to test modulatory effects of investigated substances on mechanisms leading to cell death.

Cell viability was assessed by propidium iodide (PI) or with the fluorescent dyes calcein and EtHD $24 \mathrm{~h}$ after addition of nanosilver particles (Fig. 2a) or supernatant $\left(\mathrm{Ag}^{+}\right)$(Fig. 2b). In the presence of either NAg or $\mathrm{Ag}^{+}$at a concentration of $75 \mu \mathrm{g} / \mathrm{mL}$, there was an apparent decrease in the number of living cells (47 and $60 \%$ of the control value, respectively). Zinc chelation with $20 \mu \mathrm{M}$ TPEN strongly aggravated cell death induced by $\mathrm{NAg}$ and $\mathrm{Ag}^{+}$. Addition of zinc to the cultured neurons in the concentration range of $10-50 \mu \mathrm{M}$ increased the viability of the cells in a dose-dependent manner. In nanosilver-treated cells, the positive effect of zinc was less evident and did not exceed $20 \%$, whereas in $\mathrm{Ag}^{+}$-treated cells it was more pronounced in over $90 \%$ of cells. Application of a noncompetitive antagonist of NMDA receptors (MK-801) significantly increased the number of living cells in nanosilver-treated cultures, exceeding the positive effect of zinc, by about $13 \%$. In $\mathrm{Ag}^{+}$-treated cultures, MK-801 gave neuroprotection at the same level as zinc. Positive effect of MK-801 was observed only in this type of experiments, under long-lasting exposure to $\mathrm{Ag}^{+}$(24 h). In contrast to nanosilver-treated cells, further experiments performed on cells exposed for 30-60 min to $\mathrm{Ag}^{+}$did not reveal positive effect of NMDAR antagonist.

In NAg-exposed cultures, cell viability after simultaneous addition of MK-801 and $\mathrm{ZnCl}_{2}$ to the growth medium was also assessed in order to observe potential synergistic effect. Combined effect of both neuroprotectants exceeded that derived from MK-801, increasing \% of living neurons 
Fig. 1 The influence of nanosilver and silver ions on intra- and extracellular zinc levels: a cytosolic zinc-derived fluorescence intensity measured using FluoZin-3AM in Locke medium $60 \mathrm{~s}$ after adding $75 \mu \mathrm{g} / \mathrm{mL}$ of nanosilver (NAg $75 \mu \mathrm{g} / \mathrm{mL}$ ), supernatant with ionic silver obtained from NAg solution (super 75) or the volume of serum equal to the volume of NAg, or supernatant added to the experimental system (control + serum 75 ). Changes in fluorescence intensity are presented in relation to its basal level ( $\mathrm{F} / \mathrm{Fo})$. The results are mean $\pm \mathrm{SD}$ obtained from three independent trials using separate CGC cultures and presented as means of 15 randomly selected objects. b Representative images taken in the 870th sec showing changes in fluorescence intensity in cell cultures subjected to the conditions described in (a). c zinc-derived fluorescence intensity measured using the fluorescent dye FluoZin-1 in cell lysates $\left(15 \times 10^{6}\right)$ after $30 \mathrm{~min}$ of incubation with $75 \mu \mathrm{g} / \mathrm{mL}$ of nanosilver (NAg $75 \mu \mathrm{g} / \mathrm{mL}$ ) or ionic silver (super 75) prepared as described in "Materials and Methods." The results are mean \pm SD from 6

measurements obtained from three independent cell cultures and presented as $\%$ of the fluorescence intensity in control cultures. $* P<0.05$ versus negative control (one-way ANOVA)

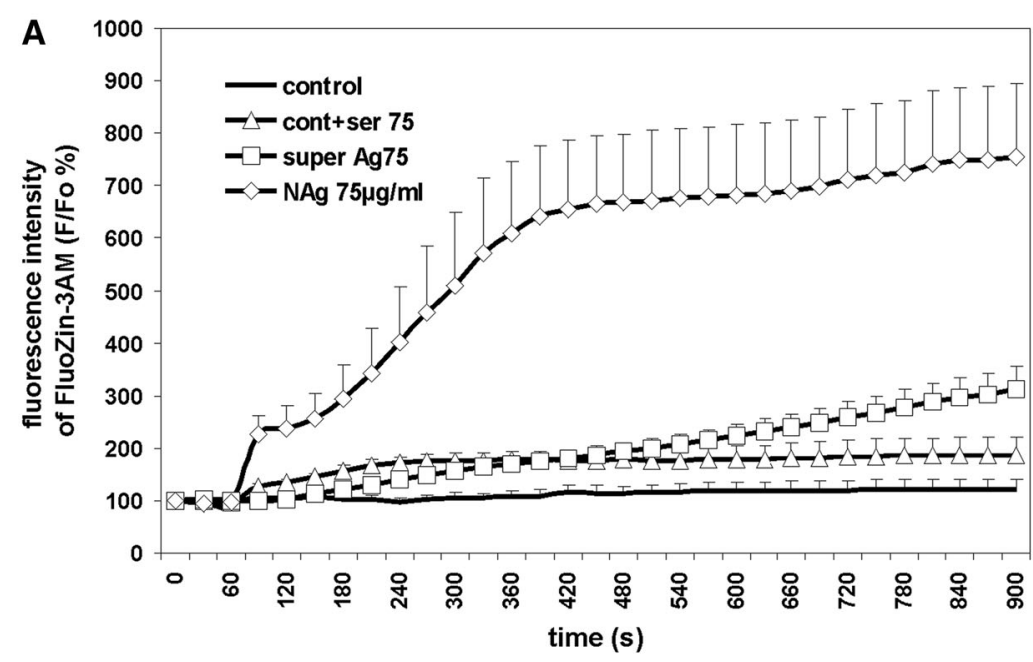

B
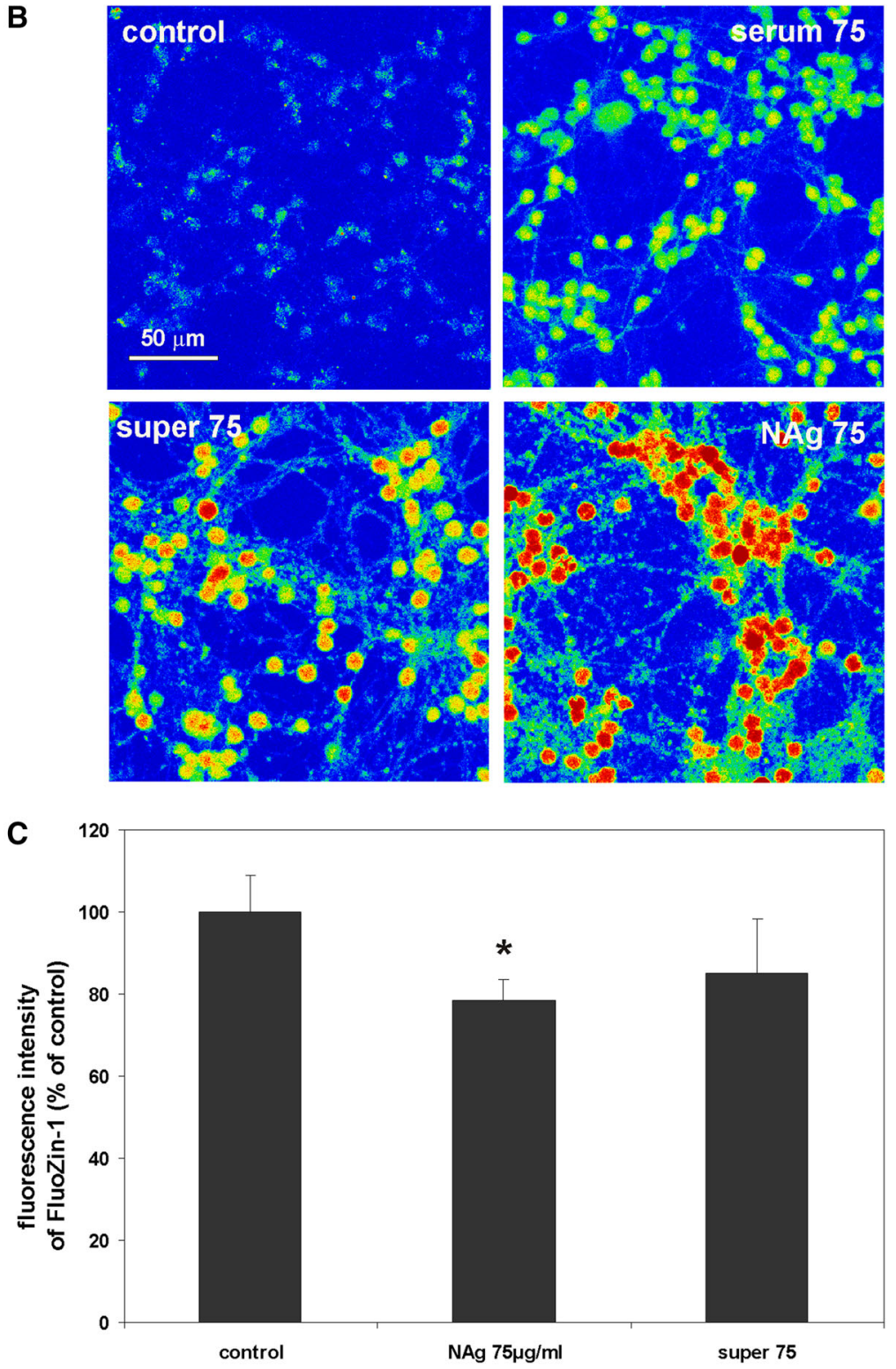
Fig. 2 The influence of TPEN, $\mathrm{ZnCl}_{2}$, MK-801, and CNQX on viability of CGCs presented as a percentage of live cells in cultures exposed for $24 \mathrm{~h}$ to $75 \mu \mathrm{g} / \mathrm{mL}$ of nanosilver (NAg $75 \mu \mathrm{g} / \mathrm{mL}$ ) or ionic silver (super 75) prepared as described in "Materials and Methods." The death effect of TPEN and the protective effect of $\mathrm{ZnCl}_{2}$ and MK-801 in a NAg-exposed cells, b ionic silver-exposed cells (super 75), c synergistic effect of $\mathrm{ZnCl}_{2}$ and MK-801 and the lack of CNQX effect in NAg-exposed cultures. The results are presented as mean \pm SD from four independent experiments. ${ }^{\#} P<0.05$ and ${ }^{\# \#} P<0.01$ versus $\mathrm{NAg} /$ super 75 -treated cells (one-way ANOVA)
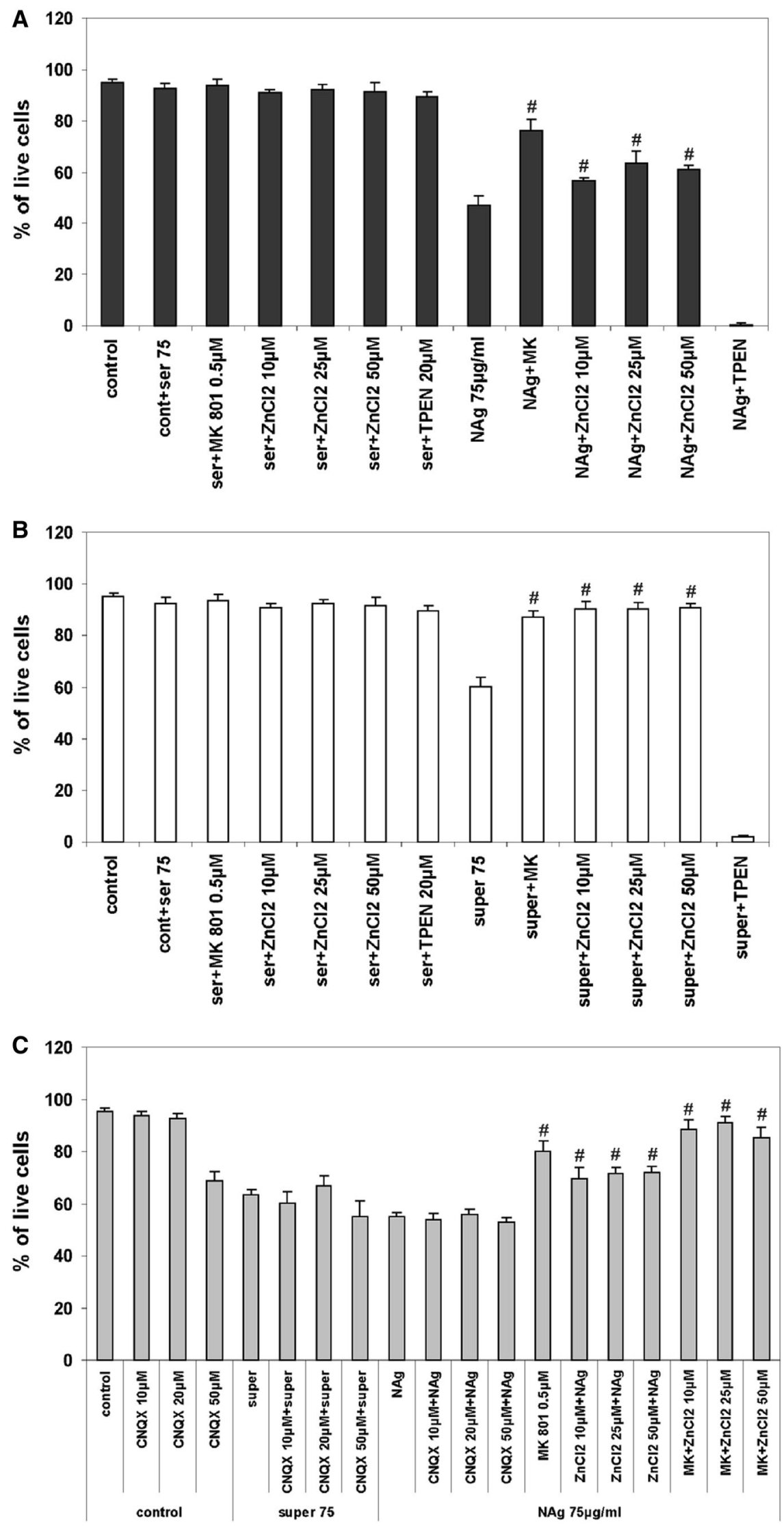
almost to the control value (91.5 vs. $95 \%$ ). However, that tendency was statistically insignificant (Fig. 2c). Since involvement of other ionotropic glutamate receptors into NAg-induced excitotoxic cell death is not excluded, we tested participation of AMPA/KA receptors in this mechanism. Receptors' antagonist CNQX was added in concentrations 10-50 $\mu \mathrm{M}$ before application of $\mathrm{NAg}$ or $\mathrm{Ag}^{+}$, but in any case, we did not notice neuroprotective effect (Fig. 2c).

Further we observed neurons after a 24-h incubation period with low concentrations of $\mathrm{NAg} / \mathrm{Ag}^{+}(2.5-10 \mu \mathrm{g} /$ $\mathrm{mL}$ ) and TPEN to investigate the effect of zinc deficiency. As we stated before, applied concentrations of nanosilver particles did not result in cell death (Ziemińska et al. 2014). However, parallel chelation of zinc influenced the appearance of nuclei in the cells (Fig. 3). Confocal images of cells visualized with propidium iodide exhibited changes in chromatin which may indicate induction of processes leading to their condensation, resembling the early changes of apoptotic nature. However, simultaneously performed tests of viability using calcein and ethidium homodimer (EtHD) showed that despite these morphological changes, the cells remain alive (Fig. 3, graph). In the case of $\mathrm{Ag}^{+}$treated cells, we did not observe a similar reaction in the presence of TPEN.

\section{Influence of Zinc on Cellular Calcium Levels and Calcium Uptake in CGCs Exposed to Nanosilver \\ ${ }^{45}$ Ca Uptake}

The treatment of cultures with nanosilver within the concentration range of $25-75 \mu \mathrm{g} / \mathrm{mL}$ increases calcium uptake by CGCs in a dose-dependent manner. The amount of calcium taken up by cells was found to be maximal in the presence of $75 \mu \mathrm{g} / \mathrm{mL}$ nanosilver and almost equal to the amount taken up during stimulation by $100 \mu \mathrm{M}$ glutamate which acts as an NMDAR agonist (the positive control in our experimental design) (Fig. 4a). TPEN added to neurons treated simultaneously with $25 \mu \mathrm{g} / \mathrm{mL}$ nanosilver significantly decreased the rate of uptake of radioactive calcium by $110 \%(* P<0.05$ vs. NAg). TPEN added to neurons treated with $50 \mu \mathrm{g} / \mathrm{mL}$ nanosilver did not influence the calcium uptake. In the presence of the highest used concentration of nanosilver $(75 \mu \mathrm{g} / \mathrm{mL})$, TPEN stimulated calcium uptake to a level similar to that attained after addition of $100 \mu \mathrm{M}$ glutamate i.e., $750 \%$ over control value; $* P<0.05$ and $66 \%$ over NAg alone (Fig. $4 \mathrm{a}$ ). Calcium uptake in CGCs incubated for 10 min with $\mathrm{Ag}^{+}$ (super 75) increased relative to control untreated cells but was lower by about $310 \%$ compared to CGCs treated with $75 \mu \mathrm{g} / \mathrm{mL}$ nanosilver TPEN exerted visible effect only when added together with the highest concentration of $\mathrm{Ag}^{+}$ (super 75), resulting in a slight increase in the rate of $\mathrm{Ca}$ uptake (Fig. 4b).

Additional supplementation of the culture medium with $10-50 \mu \mathrm{M} \mathrm{ZnCl}_{2}$ resulted in strong and dose-dependent inhibition of calcium uptake in glutamate- or nanosilvertreated cultures (about 700 and $500 \%$, respectively), so as in control cells. In $\mathrm{Ag}^{+}$-exposed cultures, the effect was less pronounced (about $200 \%$ ) (Fig. 5).

\section{Intracellular Calcium Level}

The intracellular calcium level which reflects uptake from the extracellular space and release from intracellular stores was monitored using the fluorescent dye fluo3-AM. According to the available data, virtually all fluorescent calcium probes also bind zinc ions. Changes in the fluorescence signal of these probes often reflect the simultaneously occurring changes in the concentrations of both calcium and zinc (Dineley 2007).

Previously we found that there is a $200 \%$ increase in the intracellular calcium level over the control level in CGCs after a 30-min incubation with $75 \mu \mathrm{g} / \mathrm{mL}$ nanosilver (Ziemińska et al. 2014). Moreover, we observed that the total fluo3-AM fluorescence signal recorded in neuronal cytosol after nanosilver exposure is a mixed calcium-zinc signal. The zinc-derived fluorescent component was found to be unstable, dependent upon nanosilver concentration and changes in the range of 6-35\% with addition of $10 \mu \mathrm{g} / \mathrm{mL}$ (and less) or $75 \mu \mathrm{g} / \mathrm{mL}$ nanosilver, respectively.

These results confirm that in the presence of $75 \mu \mathrm{g} / \mathrm{mL}$ nanosilver, the intracellular calcium/zinc levels (as measured by fluorescence) increase significantly $\left({ }^{*} P<0.05\right)$ by about $120 \%$ relative to control cultures (Fig. 6a). Zinc chelation by TPEN significantly decreases the $\mathrm{Ca} / \mathrm{Zn}$ signal $(* P<0.05)$. Addition of MK-801 also reduces the level of fluorescence, although this effect was found to be unstable during the incubation time. The most pronounced and time-stable blockage of the increase in intracellular $\mathrm{Ca}^{2+}$ / $\mathrm{Zn}^{2+}$ was observed after addition of $25 \mu \mathrm{M} \mathrm{ZnCl}$. The recorded signal decreased to the level of the control.

In the $\mathrm{Ag}^{+}$-exposed cultures, we did not observe such a significant increase in intracellular $\mathrm{Ca}^{2+/} \mathrm{Zn}^{2+}$ levels or reduction thereof by MK-801 (Fig. 6b). However, in the presence of $\mathrm{ZnCl}_{2}{ }^{+}$, the fluorescence signal of $\mathrm{Ca}^{2+} / \mathrm{Zn}^{2}$ was lower than in the control untreated cultures.

\section{Influence of Zinc on Mitochondrial Potential and ROS Production Under Nanosilver Toxicity Conditions}

Changes in the mitochondrial potential of CGCs were monitored using the fluorescent marker R123. Increased 
Fig. 3 Images of cell nuclei fixed with methanol and stained with propidium iodide in control CGC cultures and in cultures treated with $20 \mu \mathrm{M}$ TPEN, $10 \mu \mathrm{g} / \mathrm{mL}$ nanosilver particles (NAg) or both (NAg + TPEN). Chromatin changes are visible in cells exposed concomitantly to nanosilver and TPEN. The graph shows the results of tests for cell viability performed simultaneously with the fluorescent dies calcein and ethidium homodimer (EtHD). Although a tendency toward decreased viability of cells treated with $2.5-10 \mu \mathrm{g} / \mathrm{mL}$ nanosilver and $20 \mu \mathrm{M}$ TPEN was observed, it was found to be statistically insignificant, $P>0.05$ (one-way ANOVA). Data are presented as mean \pm SD from six independent experiments. Neurons displayed characteristics of living cells despite obvious morphological changes in the nuclei. Inserts are magnified $2 \times$
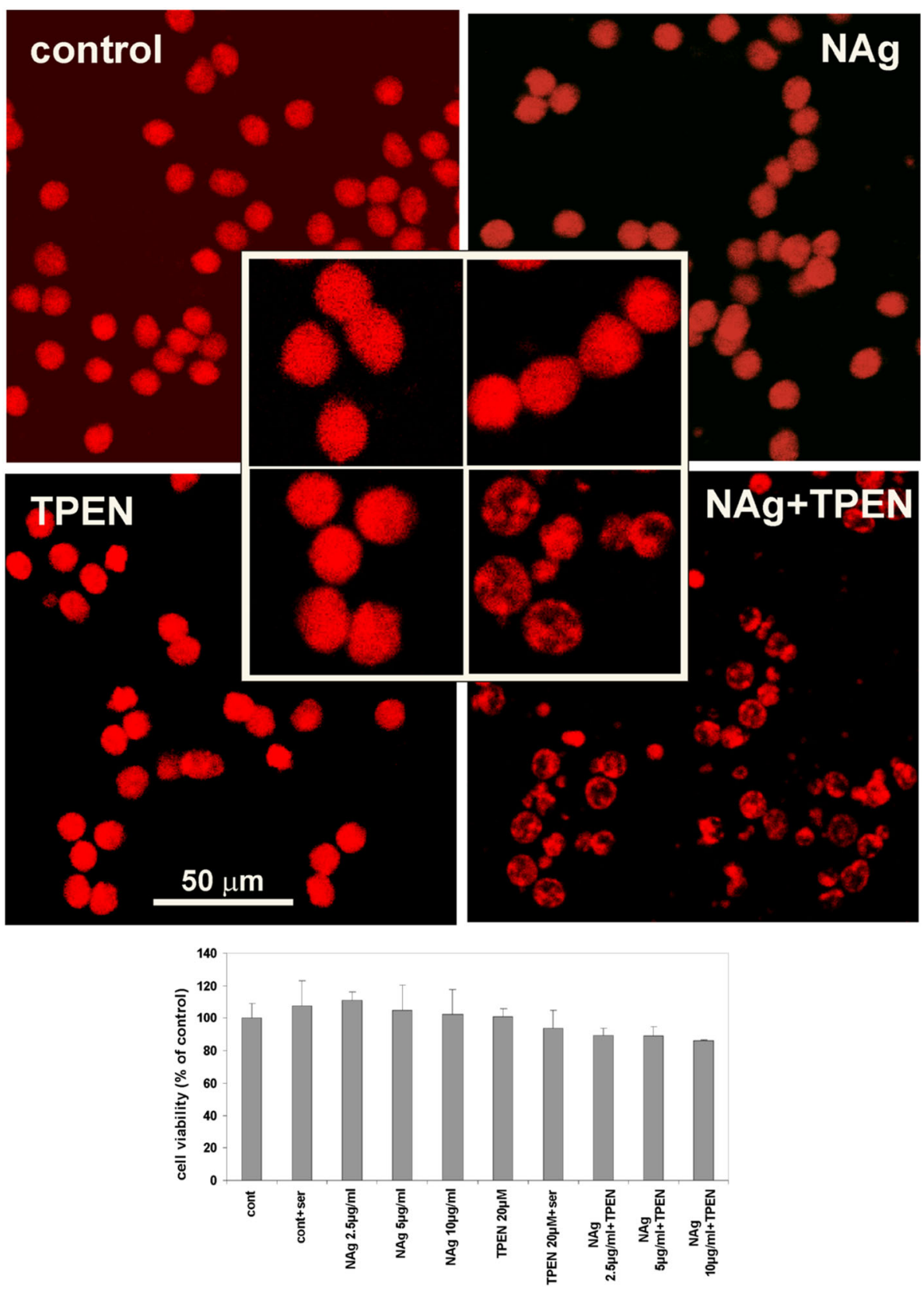

fluorescence reflects a drop in the mitochondrial membrane potential.

Exposure of cells to $75 \mu \mathrm{g} / \mathrm{mL}$ nanosilver for $60 \mathrm{~min}$ was found to induce a significant increase in the fluorescence by about $160 \%$ above the control value (Fig. 7a). MK-801 added to nanosilver-treated cultures was found to decrease this effect slightly. Supplementation of the culture medium with zinc did not improve the potential, whereas zinc deficiency ( $20 \mu \mathrm{M}$ TPEN) significantly disrupted it.

Interestingly, in the case of $\mathrm{Ag}^{+}$, we did not observe such an adverse effect of TPEN on the mitochondrial potential, while addition of $\mathrm{ZnCl}_{2}$ or MK-801 was found to stabilize the mitochondrial potential and provide a partial protective effect (Fig. 7b).

Production of ROS was determined by measuring the fluorescence intensity of DCF dye after incubation of CGCs for $30 \mathrm{~min}$ in the presence of $75 \mu \mathrm{g} / \mathrm{mL} \mathrm{NAg}$ or $\mathrm{Ag}^{+}$.

The fluorescence intensity increased significantly when TPEN was added to nanosilver-exposed cells (by about $250 \%$ ) (Fig. 8a) and moderately in $\mathrm{Ag}^{+}$-exposed cells (by about $70 \%$ ) (Fig. 8b).

ROS production increased significantly relative to the control after a 30-min incubation with NAg but not with 
Fig. 4 The effect of the zinc chelator TPEN on the uptake of radioactive calcium by $\mathrm{CGCs}$ exposed to different concentrations of a nanosilver particles $(25-75 \mu \mathrm{g} / \mathrm{mL})$ or b ionic silver (super 25-75) for 10 min. Glutamate (glu $100 \mu \mathrm{M}$ ), an agonist of NMDARs, was used as a positive control. Cultures of CGC supplemented with serum were used as a control of the serum effect (control + ser). Accumulated ${ }^{45} \mathrm{Ca}$ was measured as nuclide disintegrations per minute (DPM) and expressed as a percentage of untreated control. The results are presented as mean \pm SD from four independent experiments. ${ }^{*} P<0.05$ versus control untreated cells; ${ }^{\#} P<0.05$ versus NAg-treated cells (oneway ANOVA)
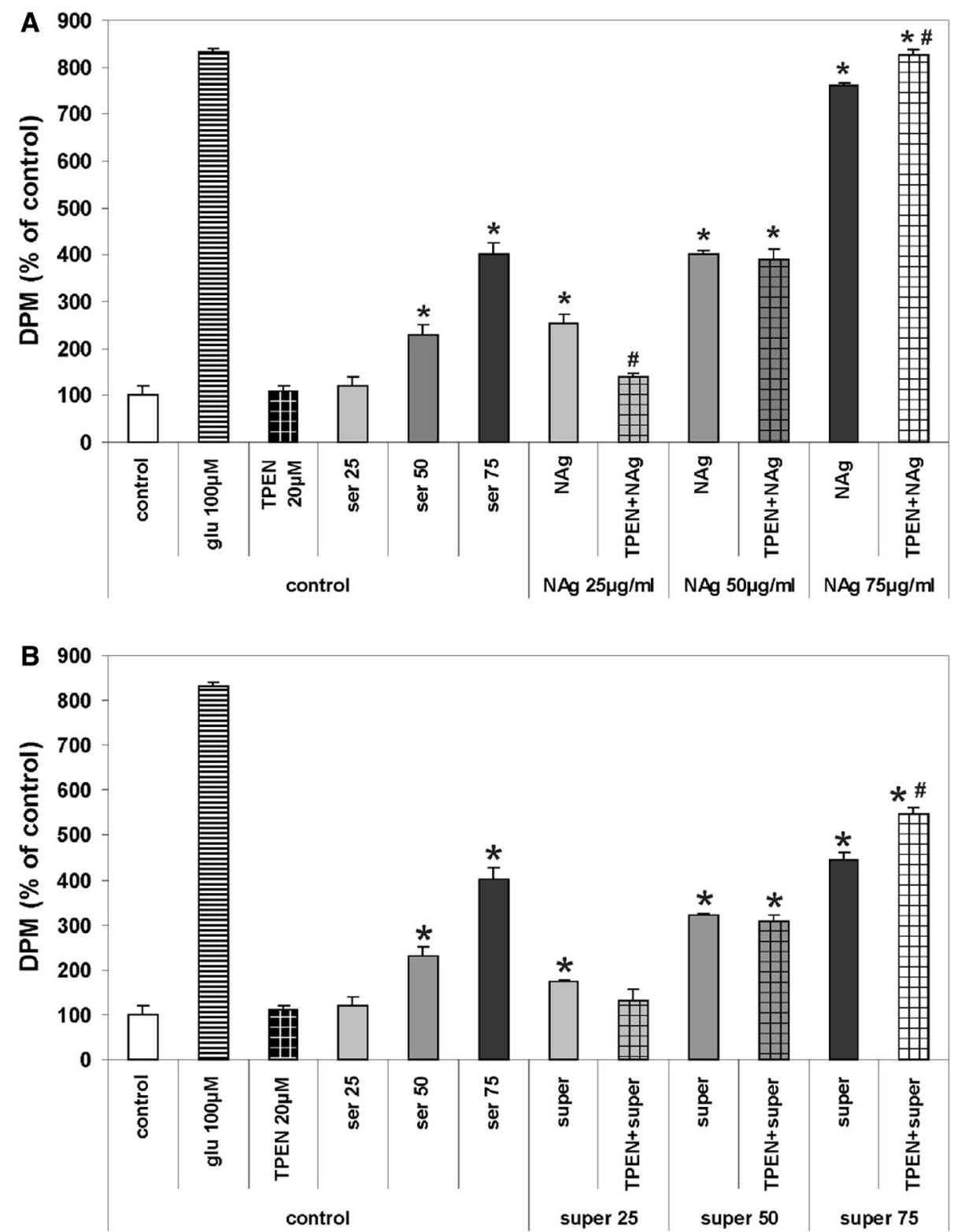

$\mathrm{Ag}^{+}$(Fig. 8c). The protective effect provided by MK-801 and $\mathrm{ZnCl}_{2}$ was observed only in nanosilver-treated cells and was found to decrease ROS level by about $40 \%$ $(* P<0.05$ vs. NAg).

\section{Discussion}

We previously assumed that nanosilver exerts its toxicity in cultured neurons by increasing the rate of the calcium entry through the channels associated with NMDA receptors (Ziemińska et al. 2014). Apart from NMDAR-related destabilization of calcium homeostasis, we also observed a progressive increase in cytosolic zinc levels in neurons under conditions of nanosilver toxicity. The contribution of zinc to the total fluorescence signal was found to be dependent upon the concentration of nanosilver. It is known that increased levels of cytosolic zinc enhance plasma membrane permeability and contribute to degenerative signaling (Medvedeva et al. 2009). The hypothesis has arisen that apart from activation of NMDAR-mediated processes, exposure to nanosilver also leads to disruption of homeostasis of intracellular zinc ions.

Thus, the objective of our present study was to investigate the neurotoxic mechanisms of silver nanoparticles in cultured rat cerebellar granule cells with particular reference to the role of zinc in nanosilver-induced biochemical changes. In order to eliminate intracellular zinc, we used a selective water-soluble and cell membrane-permeable chelator TPEN. In addition, $\mathrm{ZnCl}_{2}$ over a range of different 


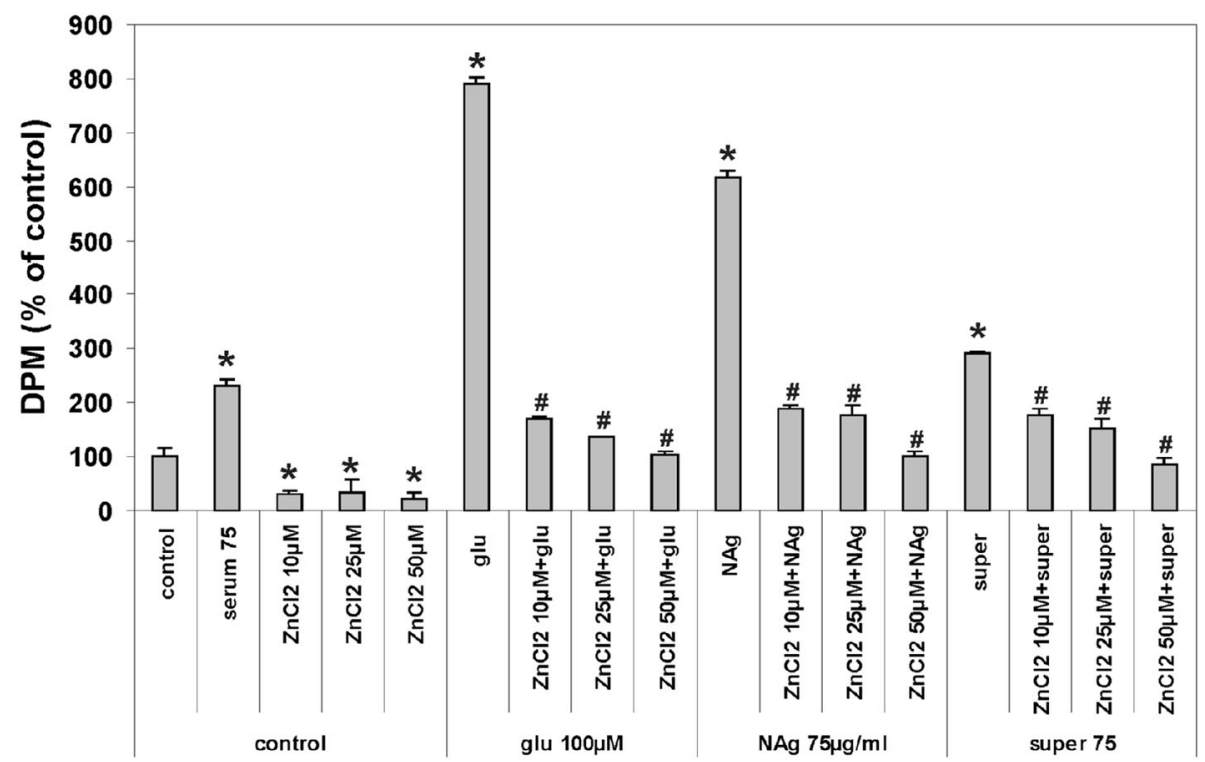

Fig. 5 The effect of zinc supplementation $(10,25$ and $50 \mu \mathrm{M} \mathrm{ZnCl}$ ) on the uptake of radioactive calcium by CGCs exposed to $75 \mu \mathrm{g} / \mathrm{mL}$ nanosilver (NAg) or ionic silver (super 75) for $10 \mathrm{~min}$. Glutamate (glu $100 \mu \mathrm{M}$ ), an agonist of NMDARs, was used as a positive control. Cultures of CGC supplemented with serum were used as a control of the serum effect (serum 75). Accumulated ${ }^{45} \mathrm{Ca}$ was measured as

concentrations $(10-50 \mu \mathrm{M})$ was used to supplement cell cultures with zinc. In our experiments, we investigated cerebellar granule neurons which are glutamate- and aspartate-receptive glutamatergic cells (Levi et al. 1991) and possess functional NMDA receptors.

The toxicity of nanoparticles depends on their concentration, size, and surface coating, as well as on the type of cells being investigated (Carlson et al. 2008; Cronholm et al. 2013). In the present study, we used nanoparticles which are coated with $0.2 \%$ PVP to prevent agglomeration. Prior to the addition to the cultures, nanoparticles should be evenly dispersed. Since sonication in water did not result in a stable dispersed form, we therefore selected serum as a medium for sonication (Park et al. 2010). In serum, nanoparticles sediment very slowly and this characteristic provides reproducibility during addition to the cultures. Moreover, it is expected to more closely replicate in vivo conditions where nanoparticles encounter blood serum proteins. However, we also characterize nanoparticles in culture media. Dispersion of nanoparticles in serum stock solution and in culture media was verified by transmission electron microscopy. As indicated in Table 1, we used nanoparticles ranging in size from 5 to $35 \mathrm{~nm}$. However, most of the particles were between 5 and $25 \mathrm{~nm}$ and are thus considered in the mid-range with respect to size and toxic potential (Carlson et al. 2008). The degree of dispersion in serum was comparable to that in both biological media. Our results are consistent with previous nuclide disintegrations per minute (DPM) and expressed as a percentage of untreated control. The results are presented as mean $\pm \mathrm{SD}$ from four independent experiments. ${ }^{*} P<0.05$ versus control untreated cells. ${ }^{\#} P<0.05$ versus NAg/super 75 -treated cells (one-way ANOVA)

reports showing that PVP-coated silver nanoparticles do not agglomerate in the presence of $10 \%$ fetal calf serum proteins. Moreover, in protein-free biological media, the presence of thiol-containing amino acids and anaerobic conditions primarily influence the dissolution of silver nanoparticles (Ahlberg et al. 2014).

\section{Changes Observed in Nanosilver-Exposed CGCs}

Based on the increased intracellular (FluoZin-3AM; Fig. 1a, b and Fluo-3; Fig. 6) and decreased total zincderived fluorescence (Fig. 1c), it can be seen that addition of nanosilver influences cellular zinc homeostasis in CGCs. Results of experiments with FluoZin-3AM show instant sevenfold increase in cytosolic Zn-derived fluorescence intensity after addition of NAg within max. $15 \mathrm{~min}$. During the time of experiment, a weak fluorescence appeared also outside the cells. Based on the high selectivity of the dye to free $\left[\mathrm{Zn}^{2+}\right]$, we claimed that cytosolic pool of free zinc increases rapidly after NAg treatment and is subsequently partially disposed out of the cell. This correlates well with drop of total zinc (cytoplasmic free + protein-bound) measured in cell lysates with FluoZin-1 after $30 \mathrm{~min}$ (Fig. 1c). Although the precise mechanisms of NAg-induced imbalance between intra/extracellular zinc levels are not known, we propose schematic explanation (Fig. 9). It appears that destabilization of cellular zinc equilibrium is partially a result of enhanced release of zinc from the 
Fig. 6 The influence of TPEN, $\mathrm{ZnCl}_{2}$ and $\mathrm{MK}-801$ on intracellular $\mathrm{Ca}^{2+} / \mathrm{Zn}^{2+}$ levels in CGCs cultured in the presence of $75 \mu \mathrm{g} / \mathrm{mL}$ nanosilver (NAg) (a) or ionic silver (super 75) (b).

Fluorescence intensity was measured using fluo-3AM and expressed as a percentage of the basal level (fluo-3AM F/Fo)

The results are presented as mean \pm SD from four independent experiments
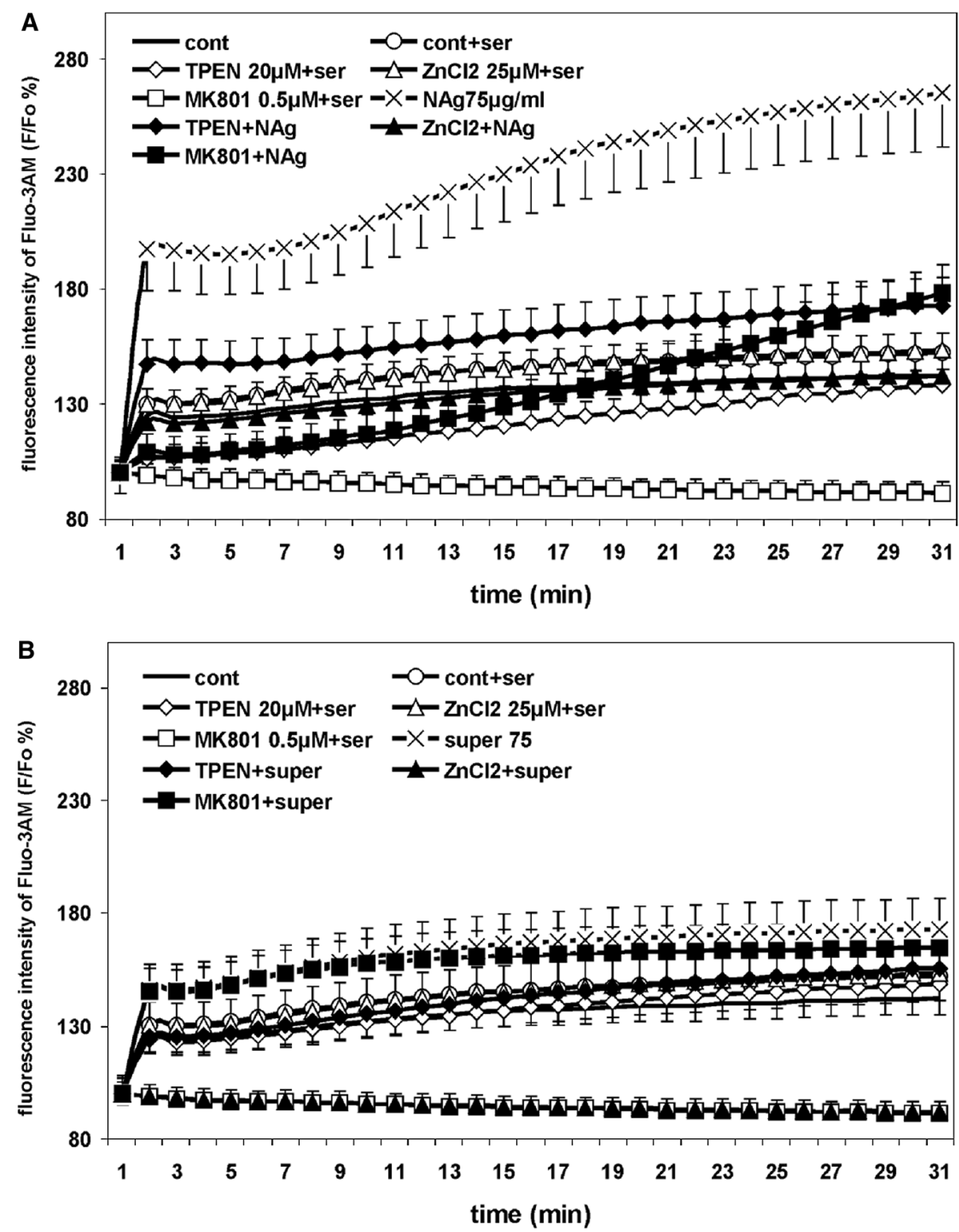

synaptic pool as a consequence of NMDAR overactivation (Fig. 9a). In CGCs, which express many functional NMDARs, zinc is co-localized with the excitatory neurotransmitter glutamate (Frederickson 1989) and may be synaptically released upon cell activation. Alternatively, enhanced efflux of zinc may be due to the activity of the plasma membrane transporter ZnT-1 which exports zinc out of the cell (Palmiter and Findley 1995) and thus may contribute to critical zinc homeostasis after exposure under depolarizing conditions (Kim et al. 2000). Since we concurrently observed an increase in intracellular zinc in nanosilver-exposed cells, the overactivation of $\mathrm{ZnT}-1$ might counteract the increased levels of cytosolic zinc. Such a protective mechanism for maintaining intracellular zinc was found to be activated following ischemia-induced toxic zinc influx (Tsuda et al. 1997). However, further studies are needed to confirm such a hypothesis. Depletion of synaptic pool of zinc together with selective accumulation of endogenous zinc in damaged neurons was previously described in ischemia, trauma, and following seizures, leading to the "translocation hypothesis", in which presynaptic zinc is first released extracellularly and then enters postsynaptic neurons mainly through AMPA receptors (Paoletti et al. 2009).

In nanosilver-treated cells, the fluorescence of fluo3-AM was found to increase significantly. Changes in the fluorescence signal of this probe often reflects the simultaneously occurring changes in the concentration of calcium and zinc (Dineley 2007). It is evident that there is an increased cytoplasmic level of "free" zinc. Previously, we 
Fig. 7 The effect of TPEN, $\mathrm{ZnCl}_{2}$, and $\mathrm{MK}-801$ on changes in the mitochondrial membrane potential in primary cultures of rat CGCs exposed to $75 \mu \mathrm{g} / \mathrm{mL}$ nanosilver (NAg) (A) or ionic silver (super 75). The basal fluorescence of cells loaded with rhodamine 123 (R123) was measured after $60 \mathrm{~s}$. Increases in R123 fluorescence reflecting a reduction in the mitochondrial membrane potential are expressed relative to the basal level (R123 F/Fo) as a percentage. The results are mean \pm SD from five independent experiments
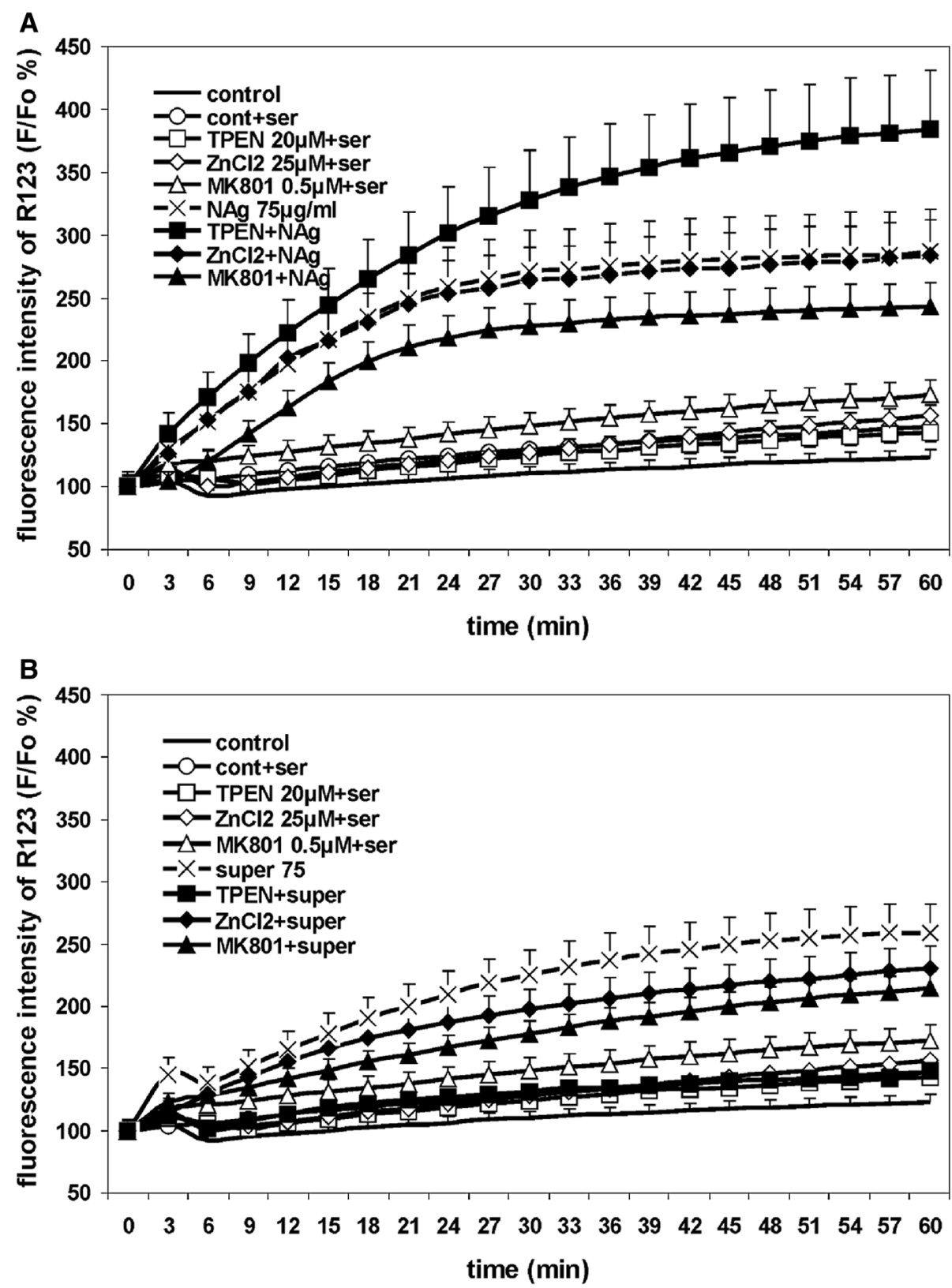

confirmed that the total fluo-3 fluorescence signal recorded in neuronal cytosol after exposure to $75 \mu \mathrm{g} / \mathrm{mL}$ nanosilver is mixed a calcium-zinc signal (Ziemińska et al. 2014) and determined the extent to which the detected signals are a result of zinc interference. The results of the current studies using FluoZin-3AM clearly confirm NAg-induced enhancement of cytoplasmic zinc level. Such an increase may represent release of zinc from the protein-bound pool or enhanced cellular entry. Glutamate receptor-induced mobilization of intracellular $\left[\mathrm{Zn}^{2+}\right]$ was proposed to be a general response to glutamate-induced oxidative stress by the mechanism dependent on $\mathrm{Ca}^{2+}$ entry (Dineley et al. 2008). Assuming that nanosilver induces overactivation of glutamatergic receptors in CGCs, elevation of extracellular glutamate may be expected. It has been shown that glutamate promotes zinc release from intracellular stores (Dineley et al. 2008) and glutamate-mediated zinc uptake is primarily dependent on voltage-gated calcium channels (VGCCs) and AMPARs (Kerchner et al. 2000; Morris and Levenson 2012).

Increased uptake of radioactive calcium, elevation of intracellular calcium, decreased mitochondrial membrane potential, increased ROS production, and decreased cell viability were additional observations made in CGCs under conditions of nanosilver toxicity (Fig. 9a). These findings are consistent with previous observations. The 10-min 
Fig. 8 The effect of TPEN, $\mathrm{ZnCl}_{2}$, and $\mathrm{MK}-801$ on generation of reactive oxygen species (ROS) in CGCs cultured in the presence of $75 \mu \mathrm{g} / \mathrm{mL}$ of nanosilver (NAg) (a) or ionic silver (super 75) (b). ROS production was monitored using the fluorescent probe DCF. The basal DCF fluorescence of cells loaded with DCF was measured after 5 min. Increases in DCF fluorescence indicating an enhanced rate of ROS production are expressed relative to the basal level (DCF $\mathrm{F} / \mathrm{Fo}$ ) as a percentage. c Generation of ROS at the 30-min time point of the experiment. The results are mean \pm SD from five independent experiments. $* P<0.05$ versus control untreated cells. ${ }^{\sharp} P<0.05$ versus NAg/super 75-treated cells
A

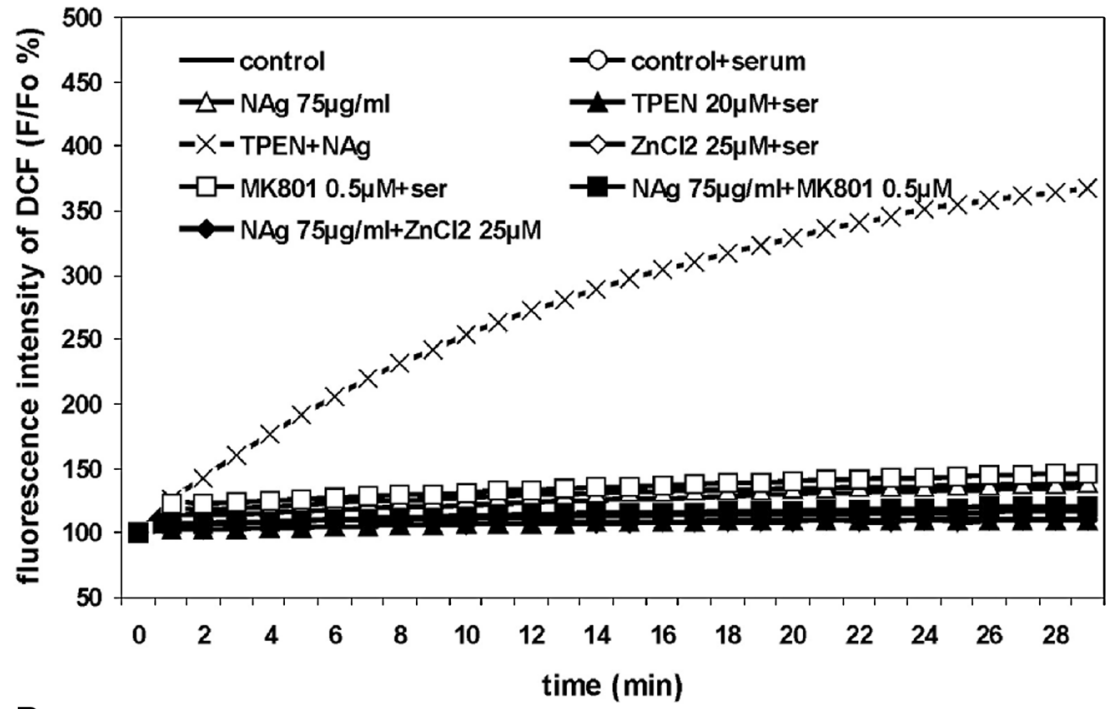

B

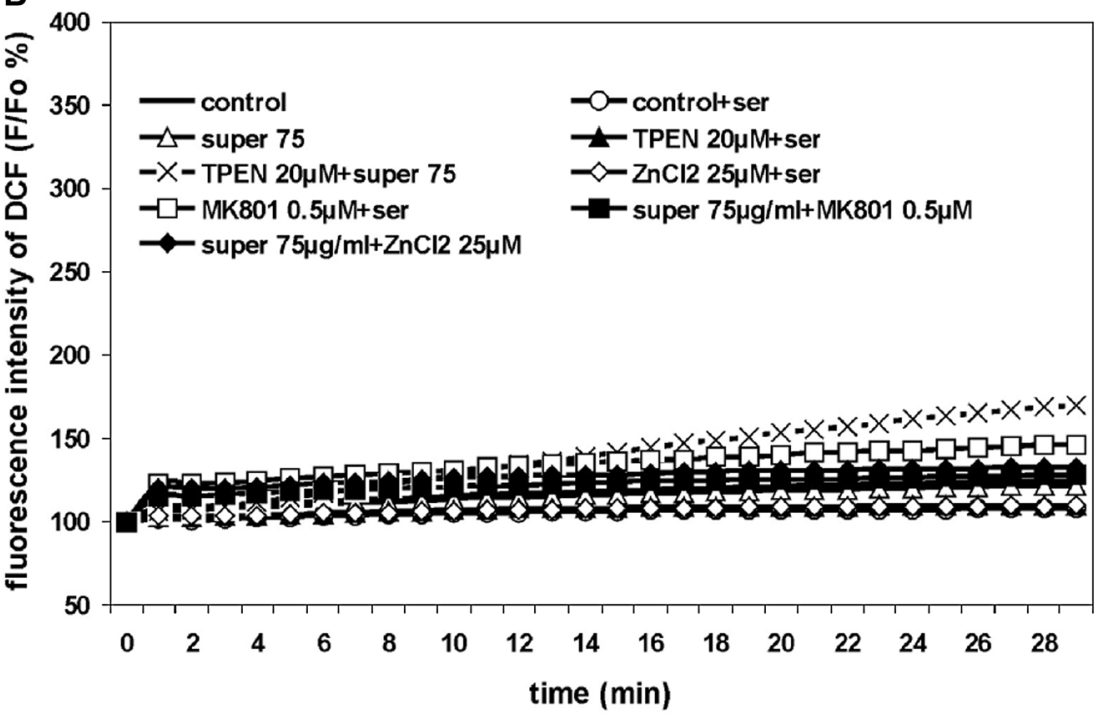

C

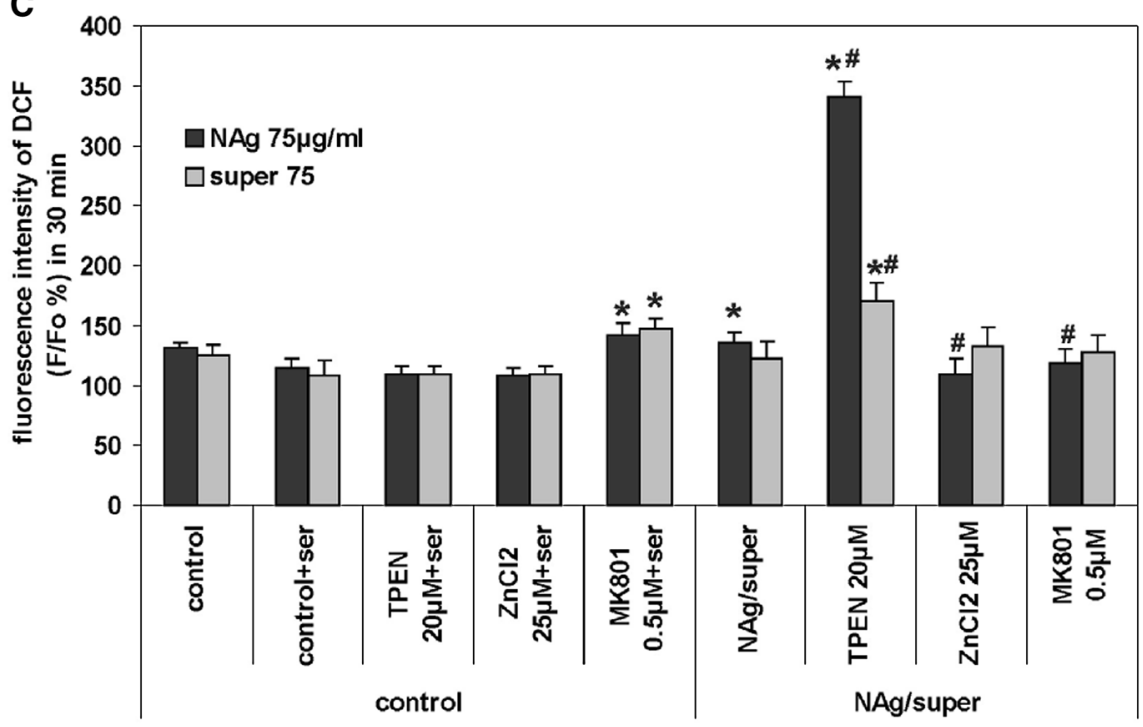



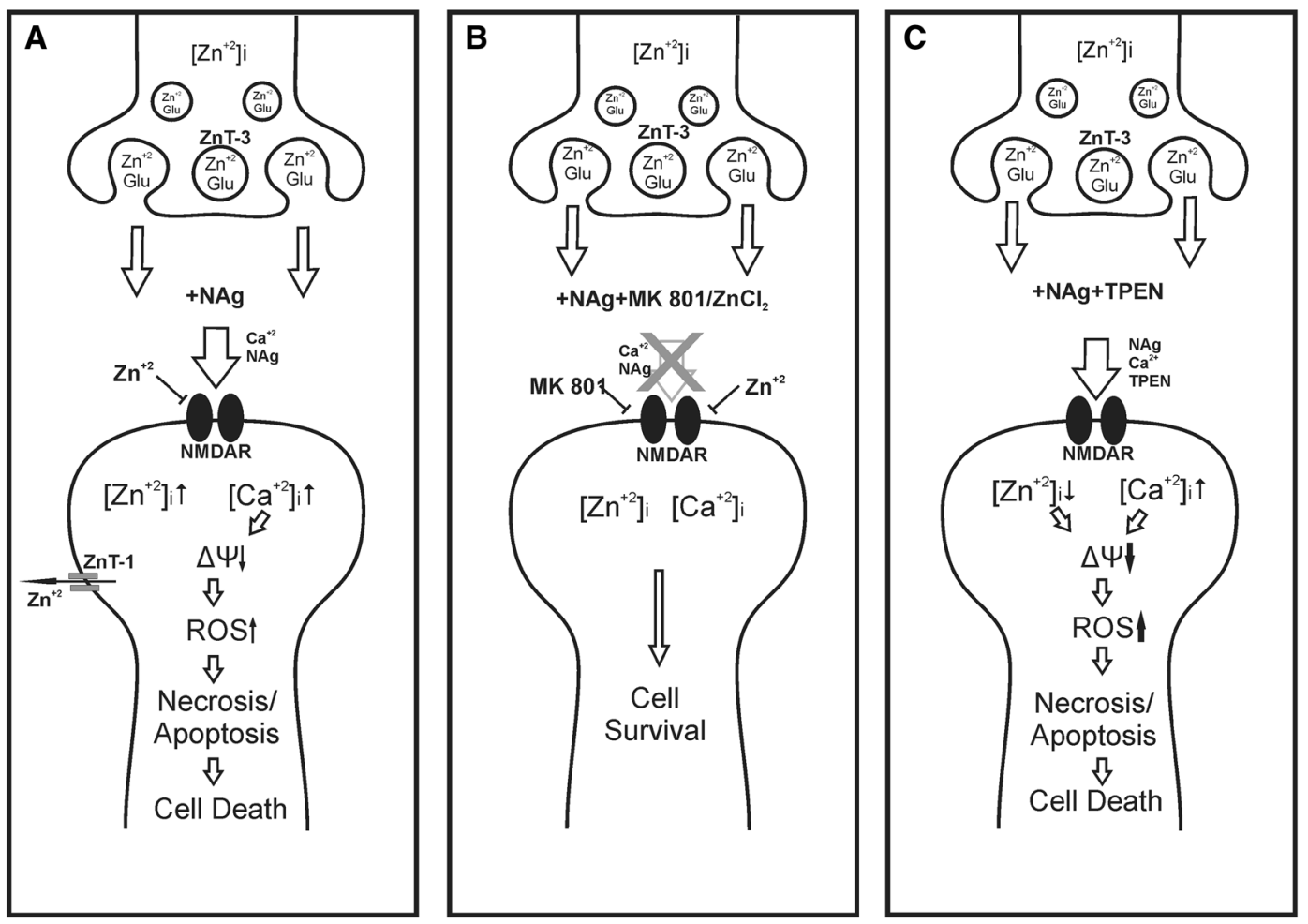

Fig. 9 Schematic representation of NAg-induced changes in CGCs a under normal conditions $\mathbf{b}$ during Zn supplementation and $\mathbf{c}$ zinc depletion by TPEN

exposure to silver nanoparticles in concentration of $75 \mu \mathrm{g} /$ $\mathrm{mL}$ was shown to intensify the entry of radioactive calcium into CGCs which even exceeded the effect evoked by $100 \mu \mathrm{M}$ glutamate (Ziemińska et al. 2014). Decreased viability of CGCs after NAg treatment was coupled to oxidative stress leading to increased intracellular calcium levels and apoptotic cell death (Yin et al. 2013).

It has been accepted that cellular mitochondria are targets for both calcium and zinc ions, where zinc may be transported through a calcium uniporter (Gazaryan et al. 2007). Silver nanoparticles also have been shown to produce disturbances in mitochondrial function (Costa et al. 2010). Our results which indicate significant loss of mitochondrial potential in nanosilver-treated cells with increased production of ROS are in agreement with the existing data. While investigating the contribution of calcium to the observed effects using MK-801 (an antagonist of NMDAR), we noted an improvement in the mitochondrial membrane potential and lowering of the level of ROS. These findings confirm that nanosilver-induced NMDARmediated disturbances in intracellular calcium homeostasis lead to mitochondrial dysfunction and generation of ROS. Whereas relatively low levels of calcium cause rapid, complete, and irreversible loss of mitochondrial membrane potential, zinc was reported to depolarize mitochondria only at relatively high concentrations via a slower, partial, and reversible manner in certain cases (Devinney et al. 2009). Thus, we suggest that the toxic effects exerted by nanosilver on cellular mitochondria are largely mediated by calcium ions.

\section{Influence of Extracellular Zinc on Nanosilver- Induced Changes in CGCs}

Zinc added in a concentration range of $10-50 \mu \mathrm{M}$ was found to significantly enhance cell viability in nanosilvertreated cultures in a manner similar to that observed upon addition of MK-801. Moreover, even though insignificantly, but added together MK- 801 and $\mathrm{ZnCl}_{2}$ increased cell viability. This indicates the involvement of an NMDAR-related mechanism. Simultaneously, the lack of positive effect of CNQX on cell viability excluded the contribution of other ionotropic glutamate receptors, like AMPA/KA receptors, to NAg-induced cell death. Indeed, unlike NMDARs, activation of these receptors generally results in very limited mitochondrial calcium loading and toxicity in CGCs (Rego et al. 2001). Thus, we assume that an "excitatory" effect of NAg selectively concerns NMDARs. Despite the fact that AMPA/KA receptors may contribute to the significant elevation of cytosolic zinc, cell 
toxicity is mainly governed by calcium. AMPARs are also less sensitive to zinc than NMDARs, being inhibited by high milimolar concentrations (Paoletti et al. 2009).

We suspect that zinc may act as a blocker of the NMDA receptor channel to prevent excessive calcium influx into the cell under conditions of receptor activation in the presence of nanosilver (Fig. 9b). Indeed, the receptor blocking effect is also clearly visible during the course of measuring radioactive calcium uptake. All concentration levels of zinc reduce both nanosilver- and glutamate-induced (agonist of NMDAR) calcium influx to CGCs. It has been demonstrated that zinc may block NMDAR currents at micromolar concentrations (Westbrook and Mayer 1987) and attenuate calcium influx through the receptor channel (Eimerl and Schramm 1993). Moreover, zinc was previously reported to inhibit acute glutamate toxicity in CGCs (Eimerl and Schramm 1991) and prevent apoptosis in a keratinocyte cell line (Parat et al. 1997).

Since NMDAR complex constitutes an ion channel selective not only for $\mathrm{Ca}^{2+}$ but also for $\mathrm{Na}^{+}, \mathrm{K}^{+}$, modulatory effect of zinc may also concern the intra/extracellular equilibrium of these cations. It is of importance because increasing intracellular $\mathrm{Na}^{+}$and $\mathrm{Ca}^{2+}$ concentrations decrease or even reverse activity of $\mathrm{Na}^{+} / \mathrm{Zn}^{2+}$ and $\mathrm{Ca}^{2+/} \mathrm{Zn}^{2+}$ exchangers (Qin et al. 2008). Elevated zinc was shown not to compromise $\mathrm{Na}^{+} / \mathrm{K}^{+}$homeostasis while acting through voltage-dependent calcium channels (VDCC) (Pivovarova et al. 2014). Modulation of NMDARactivated changes in cations homeostasis by zinc, especially under conditions of $\mathrm{NAg}$ exposure, need further study.

We observe that added zinc also decreased significantly, but not completely, ROS production after treatment with nanosilver but it was found to be ineffective with respect to improving the mitochondrial potential. Zinc has been described as being involved in cellular mechanisms of redox potential protecting thiol groups of essential proteins, and it is known that it is an essential cofactor of the stabilizing antioxidative enzyme SOD-1 (Bray and Bettger 1990). When added to the cell culture, zinc exerts a protective effect through its antioxidant activity (Richard et al. 1993).

When released from synaptic vesicles, zinc reaches an extra-synaptic concentration in the hundred micromolar range (Assaf and Chung 1984). During enhanced activity of NMDA receptors which we postulate takes place with nanosilver treatment of CGCs, even higher levels of $[\mathrm{Zn}]_{\mathrm{ex}}$ are possible. We expected that additional supplementation with 10-50 micromolar $\mathrm{ZnCl}_{2}$ would enhance nanosilver toxicity by an adjective toxic effect. The neurotoxic effect of exogenously applied zinc at a concentration of $40 \mu \mathrm{M}$ upon prolonged exposure (up to $24 \mathrm{~h}$ ) was demonstrated in vitro (Sheline et al. 2000), whereas shorter exposures were found to be cytotoxic with respect to CGCs at higher concentrations ranges 100-500 $\mu \mathrm{M}$ (Manev et al. 1997). The possibility exists, that apart from enhancing NMDAR activity, nanosilver may also interact in an inhibitory manner with other types of CGC receptor/channels which provide routes for entry of zinc into the cell, thereby reducing inward transmission of zinc ions. AMPA/kainate glutamate receptors, voltage-gated calcium channels, and the $\mathrm{Na} / \mathrm{Zn}$ antiporter are the main candidates (for a review see: Morris and Levenson 2012). It is also likely that toxic elevation of $[\mathrm{Zn}]_{\text {in }}$ is prevented by the same cellular mechanisms responsible for zinc homeostasis i.e., transporters and/or binding to metallothioneins. The ZnT-1 transporter was shown to be up-regulated during ischemiainduced toxic zinc influx (Tsuda et al. 1997), and cells overexpressing it are provided with resistance to zinc-induced death (Palmiter and Findley 1995). On the other hand, as we stated above, enhanced release of glutamate/ zinc from the synaptic pool might overactivate ZnT-3 which is responsible for transporting zinc to the synaptic vesicles and thus lowering the cytoplasmic level of zinc.

\section{Influence of Zinc Deficiency on Nanosilver-Induced Changes in CGC (TPEN Effect)}

It was demonstrated that administration of the cell membrane-permeable zinc chelator TPEN reduces zinc-induced death of cortical neurons (Canzoniero et al. 2003). This indicates that the chelator eliminates the toxic consequences of excessive zinc by restoring its cellular homeostasis.

In our experiments, elimination of zinc by TPEN led to the complete death of CGCs exposed to $75 \mu \mathrm{g} / \mathrm{mL}$ nanosilver. Moreover, concurrent exposure of cells to the low concentrations of nanosilver $(2.5-10 \mu \mathrm{g} / \mathrm{mL})$ and TPEN induced characteristic apoptotic changes in the cell nuclei, although added alone TPEN did not exert such effect (Fig. 3). It has been shown that zinc deprivation induced by addition of TPEN may lead to DNA fragmentation and trigger apoptosis (Parat et al. 1997); however, at the concentration levels used in our experiments, it evoked cell death only in the presence of nanosilver. Application of TPEN also aggravates the mitochondrial membrane and generates large amounts of free radicals (Fig. 9c). The observed toxic effects of TPEN are presumably triggered by excessive chelation of $\left[\mathrm{Zn}^{2+}\right]_{\text {in }}$ which is needed for cellular processes with subsequent loss of its antioxidant properties. The involvement of zinc in cellular redox mechanisms occurs by binding to a great number of biological molecules (Bray and Bettger 1990). Furthermore, chelation of synaptically derived zinc by TPEN abolishes its inhibitory effect on NMDAR, thereby enhancing NMDAR-mediated calcium uptake (Fig. 3), ROS 
production (Fig. 8c), and disturbing mitochondrial potential (Fig. 7). The toxic effect of TPEN observed in nanosilver-treated cells reflects pathological lowering of intracellular zinc and its availability for use as cofactors of enzymes and transcription factors.

On the other hand, the same concentrations of TPEN were found to be protective in certain experiments. We observed lowering of the intracellular calcium level in nanosilver-treated cells subjected simultaneously to TPEN (Fig. 6). This clearly indicates significant participation of a zinc-derived component in cytosolic $\mathrm{Ca}^{2+} / \mathrm{Zn}^{2+}$ fluorescence. The increased level of cytosolic zinc under nanosilver exposure is presumably connected to the overactivation of NMDAR as concluded from the reversing effect of MK-801 and $\mathrm{ZnCl}_{2}$. Thus, it is possible that nanosilver particles cause immediate disturbance of zinc homeostasis but to a low and variable extent. Possibly, a nanosilver-induced increase in cytosolic zinc measured in the experiment with fluo-3 (Fig. 6) is not high enough to induce adverse effects inside the cell.

\section{Comparing Nanosilver and $\mathrm{Ag}^{+}$Effects on CGCs}

Previous reports have discussed whether the mechanisms of silver toxicity depend on its formulation (for a review see: Hadrup and Lam 2014) and whether nanosilver interacts specifically with biological systems. It is widely accepted that $\mathrm{Ag}^{+}$is liberated from the surface of particles and may, to some extent, be responsible for the toxic effects of nanosilver. The present results and our previous report (Ziemińska et al. 2014) indicate that NMDAR-mediated toxicity is a mechanism specific for nanoparticulate but not ionic silver. Based on our previous paper (Ziemińska et al. 2014), supernatant obtained after centrifugation of a nanosilver stock solution was used as a control to recognize the component of the action resulting from $\mathrm{Ag}^{+}$ liberated from the nanoparticles.

While comparing the effects of nanosilver and $\mathrm{Ag}^{+}$on CGCs, it is clear that "nano" formulation of silver more effectively interacts with the investigated processes. Enhancement of calcium uptake, increased intracellular $\mathrm{Ca}^{2+/} \mathrm{Zn}^{2+}$ levels, and ROS production are largely nanosilver-triggered events. Our results reveal that nanosilver contributes to greater extent than $\mathrm{Ag}^{+}$to cellular toxicity. This is consistent with other reports (Yin et al. 2013).

Effective protection provided by MK- 801 is observed in most of the experiments in nanosilver- but not $\mathrm{Ag}^{+}$-treated cultures. This confirms the involvement of NMDAR in the pathological changes in CGCs as a nanosilver-specific mechanism. In contrast to nanosilver-treated cells, long lasting $(24 \mathrm{~h})$ but not short-time experiments (30-60 min) revealed positive effect of NMDAR antagonist. It is possible that NMDAR-mediated mechanisms are switched on during prolonged time of incubation with $\mathrm{Ag}^{+}$as secondary mechanisms. Likewise, zinc homeostasis was altered in nanosilver-exposed cells. This represents the most pronounced effect of zinc supplementation and intensified TPEN toxicity.

\section{Conclusions}

The results of this study stated the role of zinc in nanosilver-evoked CGC death. It is evident that exposure to increased concentrations of nanosilver leads to an imbalance between extra/intracellular zinc levels. The same does not hold true for exposure to $\mathrm{Ag}^{+}$. Excessive increase in cytosolic level of zinc with its subsequent release from glutamatergic synapses are related to the contribution of zinc in processes mediated by overactivation of NMDARs, specifically under nanosilver exposure. However, the results indicate, in contrast to our expectations, that zinc homeostasis, although altered during exposure to nanosilver, does not contribute significantly to cell death. This conclusion is supported by the observation that the zinc chelator TPEN does not eliminate toxic changes evoked by nanosilver but instead tends to increase them leading to cell death. In contrast, zinc supplementation exerts a positive effect, which is likely due to inhibiting the NMDA-sensitive glutamate-gated calcium current.

Acknowledgments This study was supported by funds from Polish Ministry of Science and Higher Education (Grant Number NN 401619938).

\section{Compliance with Ethical Standards}

Conflict of interest The authors declare that they have no conflicts of interest.

Open Access This article is distributed under the terms of the Creative Commons Attribution 4.0 International License (http://crea tivecommons.org/licenses/by/4.0/), which permits unrestricted use, distribution, and reproduction in any medium, provided you give appropriate credit to the original author(s) and the source, provide a link to the Creative Commons license, and indicate if changes were made.

\section{References}

Ahlberg S, Antonopulos A, Diendorf J, Dringen R, Epple M, Flöck R, Goedecke W, Graf C, Haberl N, Helmlinger J, Herzog F, Heuer F, Hirn S, Johannes C, Kittler S, Köller M, Korn K, Kreyling WG, Krombach F, Lademann J, Loza K, Luther EM, Malissek M, Meinke MC, Nordmeyer D, Pailliart A, Raabe J, Rancan F, Rothen-Rutishauser B, Rühl E, Schleh C, Seibel A, Sengstock C, Treuel L, Vogt A, Weber K, Zellner R (2014) PVP-coated, 
negatively charged silver nanoparticles: A multi-center study of their physicochemical characteristics, cell culture and in vivo experiments. Beilstein J Nanotechnol 5:1944-1965

Aizenman E, Stout AK, Hartnett KA, Dineley KE, McLaughlin B, Reynolds IJ (2000) Induction of neuronal apoptosis by thiol oxidation: putative role of intracellular zinc release. J Neurochem 75:1878-1888

Aschner M, Cherian MG, Klaassen CD, Palmiter RD, Erickson JC, Bush AI (1997) Metallothioneins in brain-the role in physiology and pathology. Toxicol Appl Pharm 142:229-242

AshaRani PV, Mun GLK, Hande MP, Valiyaveettil S (2009) Cytotoxicity and genotoxicity of silver nanoparticles in human cells. ACS Nano 3:279-290

Assaf SY, Chung SH (1984) Release of endogenous $\mathrm{Zn}^{2+}$ from brain tissue during activity. Nature 308:734-736

Beyersmann D, Haase H (2001) Functions of zinc in signaling, proliferation and differentiation of mammalian cells. Biometals $14: 331-341$

Bray TM, Bettge WJ (1990) The physiological role of zinc as an antioxidant. Free Radic Biol Med 8:281-291

Canzoniero LMT, Manzerra P, Sheline CT, Choi DW (2003) Membrane-permeant chelators can attenuate $\mathrm{Zn}^{2+}$-induced cortical neuronal death. Neuropharmacology 45:420-428

Carlson C, Hussain SM, Schrand AM, Braydich-Stolle LK, Hess KL, Jones RL, Schlager JJ (2008) Unique cellular interaction of silver nanoparticles: size-dependent generation of reactive oxygen species. J Phys Chem B 112:13608-13619

Costa CS, Ronconi JV, Daufenbach JF, Gonçalves CL, Rezin GT, Streck EL, Paula MM (2010) In vitro effects of silver nanoparticles on the mitochondrial respiratory chain. Mol Cell Biochem 342:51-56

Cronholm P, Karlsson HL, Hedberg J, Lowe TA, Winnberg L, Elihn K, Wallinder IO, Möller L (2013) Intracellular uptake and toxicity of $\mathrm{Ag}$ and $\mathrm{CuO}$ nanoparticles: a comparison between nanoparticles and their corresponding metal ions. Small 9:970 982

Devinney MJ, Malaiyandi LM, Vergun O, DeFranco DB, Hastings TG, Dineley KE (2009) A comparison of $\mathrm{Zn}^{2+}$ - and $\mathrm{Ca}^{2+}$ triggered depolarization of liver mitochondria reveals no evidence of $\mathrm{Zn}^{2+}$-induced permeability transition. Cell Calcium 45:447-455

Dineley KE (2007) On the use of fluorescent probes to distinguish $\mathrm{Ca}^{2+}$ from $\mathrm{Zn}^{2+}$ in models of excitotoxicity. Cell Calcium 42:341-342

Dineley KE, Devinney MJ 2nd, Zeak JA, Rintoul GL, Reynolds IJ (2008) Glutamate mobilizes $\left[\mathrm{Zn}^{2+}\right]$ through $\mathrm{Ca}^{2+}$-dependent reactive oxygen species accumulation. J Neurochem 106:21842193

Eimerl S, Schramm M (1991) Acute glutamate toxicity in cultured cerebellar granule cells: agonist potency, effects of $\mathrm{pH}, \mathrm{Zn}^{2+}$ and the potentiation by serum albumin. Brain Res 560:282-290

Eimerl S, Schramm M (1993) Potentiation of ${ }^{45} \mathrm{Ca}$ uptake and acute toxicity mediated by the $N$-methyl-D-aspartate receptor: the effect of metal binding agents and transition metal ions. J Neurochem 61:518-525

Frederickson CJ (1989) Neurobiology of zinc and zinc-containing neurons. Int Rev Neurobiol 31:145-238

Gazaryan IG, Krasinskaya IP, Kristal BS, Brown AM (2007) Zinc irreversibly damages major enzymem of energy production and antioxidant defense prior to mitochondria mitochondria permeability transition. J Biol Chem 282:24373-24380

Haase A, Rott S, Mantion A, Graf P, Plendl J, Thünemann AF, Meier WP, Taubert A, Luch A, Reiser G (2012) Effects of silver nanoparticles on primary mixed neural cell cultures: uptake, oxidative stress and acute calcium responses. Toxicol Sci $126: 457-468$
Hadrup N, Lam HR (2014) Oral toxicity of silver ions, silver nanoparticles and colloidal silver-a review. Reg Toxicol Pharmacol 68:1-7

Harrison NL, Gibson SJ (1994) Zn2 + : an endogenous modulator of ligand-gated ion channels. Neuropharmacology 33:935-952

Hoet PH, Brüske-Hohlfeld I, Salata OV (2004) Nanoparticlesknown and unknown health risks. J Nanobiotechnol 2:12

Hussain SM, Hess KL, Gearhart JM, Geiss KT, Schlager JJ (2005) In vitro toxicity of nanoparticles in BRL $3 \mathrm{~A}$ rat liver cells. Toxicol In Vitro 19:975-983

Kerchner GA, Canzoniero LM, Yu SP, Ling C, Choi DW (2000) $\mathrm{Zn}^{2+}$ current is mediated by voltage-gated $\mathrm{Ca}^{2+}$ channels and enhanced by extracellular acidity in mouse cortical neurons. J Physiol 528:39-52

Kim AH, Sheline CT, Tian M, Higashi T, McMahon RJ, Cousins RJ, Choi DW (2000) L-type $\mathrm{Ca}(2+)$ channel-mediated $\mathrm{Zn}(2+)$ toxicity and modulation by ZnT-1 in PC12 cells. Brain Res 886:99-107

Kittler S, Greulich C, Diendorf J, Köller M, Epple M (2010) Toxicity of silver nanoparticles increases during storage because of slow dissolution under release of silver ions. Chem Mater 22:4548-4554

Koh JY, Suh SW, Gwag BJ, He YY, Hsu CY, Choi DW (1996) The role of zinc in selective neuronal death after transient global cerebral ischemia. Science 272:1013-1016

Leite PE, Pereira MR, Granjeiro JM (2015) Hazard effects of nanoparticles in central nervous system: searching for biocompatible nanomaterials for drug delivery. Toxicol In Vitro 29:1653-1660

Levi G, Patrizio M, Gallo V (1991) Release of endogenous and newly synthesized glutamate and of other amino acids induced by non$\mathrm{N}$-methyl-D-aspartate receptor activation in cerebellar granule cell cultures. J Neurochem 56:199-206

Lobner D, Canzoniero LMT, Gottron F, Ying H, Knudson CM, Tian M, Dugan LL, Corsmeyer SJ, Kerchner GA, Choi DW (2000) Zinc-induced neuronal death in cortical neurons. Cell Mol Biol 46:797-806

Lozier ER, Stelmashook EV, Uzbekov RE, Novikova SV, Zorov SD, Alieva IB, Arbeille B, Zorov DB, Isaev NK (2012) Stimulation of kainate toxicity by zinc in cultured cerebellar granule neurons and the role of mitochondria in this process. Toxicol Lett 208:36-40

Manev H, Kharlamov E, Uz T, Mason RP, Cagnoli CM (1997) Characterization of zinc-induced neuronal death in primary cultures of rat cerebellar granule cells. Exp Neurol 146:171-178

Medvedeva YV, Lin B, Shuttleworth CW, Weiss JH (2009) Intracellular $\mathrm{Zn}^{2+}$ accumulation contributes to synaptic failure, mitochondrial depolarization and cell death in an acute slice oxygen-glucose deprivation model of ischemia. J Neurosci 29:1105-1114

Morris DR, Lavensonn CW (2012) Ion channels and zinc: mechanisms of neurotoxicity and neurodegeneration. J Toxicol ID: 785647

Palmiter RD, Findley SD (1995) Cloning and functional characterization of a mammalian zinc transporter that confers resistance to zinc. EMBO J 14:639-649

Paoletti P, Vergnano AM, Barbour B, Casado M (2009) Zinc at glutamatergic synapses. Neuroscience 158:126-136

Parat MO, Richard MJ, Pollet S, Hadjur C, Favie A, Béani JC (1997) Zinc and DNA fragmentation in keratinocyte apoptosis: its inhibitory effect in UVB irradiated cells. J Photochem Photobiol B 37:101-106

Park EJ, Yi J, Kim Y, Choi K, Park K (2010) Silver nanoparticles induce cytotoxicity by a Trojan-horse type mechanism. Toxicol In Vitro 24:872-878

Peters S, Koh J, Choi DW (1987) Zinc selectively blocks the action of $N$-methyl-D-aspartate on cortical neurons. Science 236:589-593 
Piao MJ, Kang KA, Lee IK, Kim HS, Kim S, Choi JY, Choi J, Hyun JW (2011) Silver nanoparticles induce oxidative cell damage in human liver cells through inhibition of reduced glutathione and induction of mitochondria-involved apoptosis. Toxicol Lett 201:92-100

Pivovarova NB, Stanika RI, Kazanina G, Villanueva I, Andrews SB (2014) The interactive roles of zinc and calcium in mitochondrial dysfunction and neurodegeneration. J Neurochem 128:592-602

Qin Y, Thomas D, Fontaine CP, Colvin RA (2008) Mechanisms of $\mathrm{Zn}^{2+}$ efflux in cultured cortical neurons. J Neurochem 107: $1304-1313$

Rego AC, Ward MW, Nicholls DG (2001) Mitochondria control ampa/kainate receptor-induced cytoplasmic calcium deregulation in rat cerebellar granule cells. J Neurosci 21:1893-1901

Richard MJ, Guiraud P, Leccia MT, Beani JC, Favier A (1993) Effect of zinc supplementation on resistance of cultured human skin fibroblasts toward oxidant stress. Biol Trace Elem Res 37:187199

Samuel U, Guggenbichler JP (2004) Prevention of catheter-related infections: the potential of a new nano-silver impregnated catheter. Int J Antimicrob Agent 23(Suppl 1):S75-S78

Schluesener JK, Schluesener HJ (2013) Nanosilver: application and novel aspects of toxicology. Arch Toxicol 87:569-576

Sensi SL, Canzoniero LM, Yu SP, Ying HS, Koh JY, Kerchner GA, Choi DW (1997) Measurement of intracellular free zinc in living cortical neurons: routes of entry. J Neurosci 17:9554-9564

Sharma HS, Ali SF, Hussain SM, Schlager JJ, Sharma A (2009) Influence of engineered nanoparticles from metals on the bloodbrain barrier permeability, cerebral blood flow, brain edema and neurotoxicity. An experimental study in the rat and mice using biochemical and morphological approaches. J Nanosci Nanotechnol 9:5055-5072

Sheline CT, Behrens MM, Choi DW (2000) Zinc-induced cortical neuronal death: contribution of energy failure attributable to loss of $\mathrm{NAD}(+)$ and inhibition of glycolysis. J Neurosci 20:31393146

Singh RP, Ramarao P (2012) Cellular uptake, intracellular trafficking and cytotoxicity of silver nanoparticles. Toxicol Lett 213:249259

Sobieszczańska M, Tubek S, Szyguła R, Bunio A (2012) Is the zinc neuroprotective effect caused by prevention of intracellular zinc accumulation? Adv Clin Exp Med 21:245-248
Struzynski W, Dabrowska-Bouta B, Grygorowicz T, Zieminska E, Struzynska L (2014) Markers of oxidative stress in hepatopancreas of crayfish (Orconectes limosus, Raf.) experimentally exposed to nanosilver. Environ Toxicol 29:1283-1291

Tønder N, Johansen FF, Frederickson CJ, Zimmer J, Diemer NH (1990) Possible role of zinc in the selective degeneration of dentate hilar neurons after cerebral ischemia in the adult rat. Neurosci Lett 109:247-252

Trombley PQ, Horning MS, Blakemore LJ (2000) Interactions between carnosine and zinc and copper: implications for neuromodulation and neuroprotection. Biochemistry (Mosc) 65:807-816

Tsuda M, Imaizumi K, Katayama T, Kitagawa K, Wanaka A, Tohyama M, Takagi T (1997) Expression of zinc transporter gene, ZnT-1, is induced after transient forebrain ischemia in the gerbil. J Neurosci 17:6678-6684

Vallee BL, Falchuk KH (1993) The biochemical basis of zinc physiology. Physiol Rev 73:79-118

Westbrook GL, Mayer ML (1987) Micromolar concentrations of $\mathrm{Zn}^{2+}$ antagonize NMDA and GABA responses of hippocampal neurons. Nature 328:640-643

Yin N, Liu Q, Liu J, He B, Cui L, Li Z, Yun Z, Qu G, Liu S, Zhou Q, Jiang G (2013) Silver nanoparticle exposure attenuates the viability of rat cerebellum granule cells through apoptosis coupled to oxidative stress. Small 9:1831-1841

Zheng Z, Yin W, Zara JN, Li W, Kwak J, Mamidi R, Lee M, Siu RK, Ngo R, Wang J, Carpenter D, Zhang X, Wu B, Ting K, Soo C (2010) The use of BMP-2 coupled-nanosilver-PLGA composite grafts to induce bone repair in grossly infected segmental defects. Biomaterials 31:9293-9300

Zieminska E, Toczylowska B, Stafiej A, Lazarewicz JW (2010) Low molecular weight thiols reduce thimerosal neurotoxicity in vitro: modulation by proteins. Toxicology 276:154-163

Zieminska E, Stafiej A, Strużyńska L (2014) The role of the glutamatergic NMDA receptor in nanosilver-evoked neurotoxicity in primary cultures of cerebellar granule cells. Toxicol 315:38-48 